\title{
Uncertainty, Risk, and Incentives: Theory and Evidence*
}

\author{
Zhiguo $\mathrm{He}^{\dagger} \quad \mathrm{Si} \mathrm{Li}^{\ddagger} \quad \mathrm{Bin} \mathrm{Wei}^{\S} \quad$ Jianfeng $\mathrm{Yu}^{\natural}$
}

January 2012

\begin{abstract}
Uncertainty has qualitatively different implications than risk in studying executive incentives. We study the interplay between profitability uncertainty and moral hazard, where profitability is multiplicative with the managerial effort. Investors who face greater uncertainty desire faster learning, and consequently offer higher managerial incentives to induce higher effort from the manager. In contrast to the standard negative risk-incentive tradeoff, this "learning-by-doing" effect generates a positive relation between profitability uncertainty and incentives. We document strong empirical support for this prediction.
\end{abstract}

Key Words: Executive Compensation, Optimal Contracting, Learning, Uncertainty, Risk-Incentive Trade-off.

${ }^{*}$ This work does not necessarily reflect the views of the Federal Reserve System or its staff. All errors are our own.

${ }^{\dagger}$ University of Chicago, Booth School of Business, 5807 South Woodlawn Ave., Chicago 60637, Phone: 773-834-3769, Email: zhiguo.he@chicagobooth.edu.

${ }^{\ddagger}$ Wilfrid Laurier University, School of Business and Economics, 75 University Avenue West, Waterloo, ON N2L 3C5, Canada. Phone: (1)519-884-0710×2395, Email: sli@wlu.ca.

${ }^{\S}$ Board of Governors of the Federal Reserve System, Washington, DC, 20551, Phone: (202)-452-2693; Fax: (202)-728-5887; Email: bin.wei@frb.gov. Also the City University of New York, Zicklin School of Business, Baruch College, 55 Lexington Avenue, New York, NY 10010. Phone: (1)646-312-3469, Email: bin.wei@baruch.cuny.edu.

ฯUniversity of Minnesota, Carlson School of Management, CSOM 3-122, 321 19th Avenue South, Minneapolis, MN 55455. Phone: (1)612-625-5498. Email: jianfeng@umn.edu. 


\section{Introduction}

A central prediction of the principal-agent theory is the negative trade-off between risk and incentives (Holmstrom and Milgrom, 1987). Higher performance pay induces greater effort from the agent but increases the risk on his compensation, which in turn raises risk compensation in the wage cost. The greater the output risk, the higher the risk compensation, leading to a lower performance pay to the risk-averse agent in the optimal contract. Yet, numerous studies over the past two decades find mixed empirical evidence on such a negative relation between risk and incentives. ${ }^{1}$

It is important to acknowledge that the empirically measured risk, which is essentially performance variance, can come from either the cash flow risk or the project's profitability uncertainty. More specifically, in many types of economic environment with agency relationships, current output not only consists of the manager's effort and some transitory random noise (i.e., the cash flow risk), but more importantly, the unobserved long-run profitability of the project (i.e., profitability uncertainty, or simply uncertainty). However, little attention has been paid to uncertainty in the principal-agent literature, although uncertainty has been shown to be important in explaining many phenomena in various markets (e.g., Pastor and Veronesi (2003)). ${ }^{2}$

In this paper, we examine how the endogenous learning on the firm's profitability uncertainty impacts executive incentives when investors seek for signals to improve the firm's future investment decision. In contrast to the negative risk-incentive relation generated by standard agency theories, in a wide parameter range, our model predicts a positive relation between the degree of profitability uncertainty and incentives. This positive uncertainty-incentive relation is strongly supported by our empirical analysis. Moreover, our findings imply that it is important to distinguish cash flow risk from profitability uncertainty in studying executive incentives, and suggest that the previous mixed empirical results in testing the negative riskincentive trade-off may be attributable to the positive bias caused by omitting variables that are proxies for profitability uncertainty.

\footnotetext{
${ }^{1}$ Prendergast (2002) reviews more than two dozen empirical studies and concludes that the evidence on the risk-incentive trade-off using the executive compensation data is inconclusive, with some studies supporting a positive or insignificant relation between risk and incentives while others finding a negative relation. See Prendergast (2002) for the references therein. We explain the difference between our model and Prendergast (2002) in footnote 3. We also provide a detailed description of the empirical literature on the risk-incentive trade-off near the end of introduction.

${ }^{2}$ Most of the existing principal-agent literature assumes that the productivity of managerial input is known. Our paper introduces the uncertainty on the productivity parameters in a simple two-period setting to illustrate our intuition on the relation between incentives, risk, and uncertainty.
} 
Our model is cast in a two-period investment setting with moral hazard in the first period. At period 1 the firm hires a manager to provide managerial labor, and the project generates an output of $y_{1}=$ $\theta\left(K_{1}+L_{1}\right)+\epsilon_{1}$, where $K_{1}$ is the capital, $L_{1}$ is the the manager's labor (effort) input, and $\epsilon_{1}$ is the exogenous cash flow shock.

Motivated by the neoclassical investment literature, the parameter $\theta$ is the project's marginal productivity, or the project's profitability. The profitability $\theta$ is unknown, and investors need better information on $\theta$ to guide future investment decisions. The key of the model is that, thanks to the $A K$ technology where the labor is multiplicative with $\theta$, a higher labor input can increase the information-to-noise ratio when investors learn the project's profitability $\theta$ from the output signal $y_{1}$ using Bayes' rule.

At period 2, the firm with the same technology adjusts capital $K_{2}$ through investment, and resets the labor input $L_{2}$. Therefore, to optimize over the period-2 investment, investors desire faster learning (i.e., they prefer to reduce the posterior variance of $\theta$ ) from the first-period output signal $y_{1}$. Because the information content of the output increases with managerial effort in the first period, investors would like to offer a high powered contract to induce higher effort so as to learn more about the unobservable profitability $\theta$. Moreover, the higher the degree of profitability uncertainty, the greater the reduction of the posterior variance of $\theta$, and therefore the greater the benefit in inducing a higher period 1 effort. Under this channel, firms with uncertain long-run profitability are offering high-power incentives to their managers for more informative signals in guiding their investment policies, which could lead to a positive uncertainty-incentive relation. ${ }^{3}$ Our mechanism is similar in spirit to the learning-by-doing literature (e.g., Jovanovic and Lach (1989), Jovanovic and Nyarko (1996), and Johnson (2007)). ${ }^{4}$

We empirically test the positive uncertainty-incentive relation in Section 3. Following Pastor and Veronesi (2003) and Korteweg and Polson (2009) we use firm age as our first proxy, with older firms indicating lower uncertainty. We also follow Pastor et al. (2009) and use the stock price reaction to earnings announcements (i.e., earnings response coefficient or ERC) as another proxy for profitability uncertainty. Intuitively, investors who are more uncertain about the profitability of a company should

\footnotetext{
${ }^{3}$ Our paper is also related to Prendergast (2002) and some other papers (see, e.g., Zabojnik (1996), and Baker and Jorgensen (2003)) that predict a possible positive relation between uncertainty and incentives. However, their mechanisms are drastically different and do not feature learning. For example, Prendergast (2002) argues that in a more uncertain environment that the agent knows more than the principal, the positive value of delegating responsibilities to the agent may dominate the negative effect of risk on incentives, resulting in a positive relation between uncertainty and incentives. By contrast, our model has symmetric information along the equilibrium path, and learning is the key mechanism.

${ }^{4}$ For instance, Johnson (2007) shows that when return-to-scale in the production function is unknown in advance, overinvestment relative to the full-information case becomes optimal, as overinvestment expedites learning about the production function.
} 
be more responsive to earnings surprises. Our other proxies for profitability uncertainty are market-tobook, tangibility, and analyst forecast error. A higher market-to-book ratio or a lower tangibility ratio indicates greater profitability uncertainty (Korteweg and Polson (2009)). Analyst forecast errors are used in the literature to proxy for uncertainty about future earnings (e.g., Lang and Lundholm (1996)). We then measure incentives using pay performance sensitivities (PPS henceforth) and run panel regressions of PPS on profitability uncertainty proxies, controlling for the factors known to affect PPS. Consistent with our model prediction, we find that firm age and tangibility are negatively related to the incentive variable PPS; and ERC, market-to-book ratio, and analyst forecast error are positively related to PPS. Although each individual proxy for uncertainty may not be perfect, the consistent results obtained from all the five proxies seem to support our theoretical prediction of a positive uncertainty-incentive relation.

Our paper provides the first systematic empirical analysis of the effects of profitability uncertainty on CEO incentives. ${ }^{5}$ We find support to our theoretical prediction that uncertainty has a positive impact on incentives. More importantly, in the view of our paper, once acknowledging that the risk measures proposed by the previous literature may well be contaminated by profitability uncertainty, it is not surprising that the empirical evidence for negative risk-incentive trade-off has been mixed. For instance, Aggarwal and Samwick $(1999,2002,2003)$ find that the rank of dollar return volatility is negatively associated with pay performance sensitivities. ${ }^{6}$ Becker (2006), Bushman et al. (1996), and Yermack (1995), however, do not find any significant impact of percentage stock return volatility on incentives, and Core and Guay (1999) obtain a positive effect of idiosyncratic risk on incentives. ${ }^{7}$ We argue that it is important to include profitability uncertainty variables in empirical specifications. Indeed, we find evidence that controlling

\footnotetext{
${ }^{5}$ Although some studies have examined the relation between incentives and the market-to-book ratio, and that between incentives and tangibility (Bizjak, et al., 1993; Core and Guay, 1999; Himmelberg, et al., 1999; Coles, et al., 2006), these studies are not in the context of the relation between uncertainty and incentives. We are not aware of any study that specifically examines the relation between incentives and ERC, analyst forecast error, and firm age.

${ }^{6}$ Garvey and Milbourn (2003) and Jin (2002) confirm this negative relation, and further find that the rank of idiosyncratic dollar return volatility is negatively related to incentives while firm systematic risk is not significantly related to incentives. Core, et al. (2003) and Lambert and Larcker (1987) find that the relative weight on stock price performance measures in CEO pay is a decreasing function of the stock return variance. Bitler et al. (2005) measure firm risk as the absolute value of the residual of the profit to equity ratio regressed on various firm and managerial characteristics, and find that entrepreneurial ownership shares decrease with firm risk. Himmelberg et al. (1999) show that idiosyncratic risk (measured using percentage return variance) is negatively related to managerial equity ownership.

${ }^{7}$ Other papers in this camp include Garen (1994), who finds that neither systematic risk nor idiosyncratic risk has any significant effect on incentives, and Conyon and Murphy (2000), who show that the relation between risk and incentives is insignificant or positive, depending on the empirical approach used. In addition, Bizjak, Brickley, and Coles (1993) find no relation between incentives and firm risk. Coles, Daniel and Naveen (JFE, 2006) find that the relation between incentives and firm risk varies in the form of the regression specification. Prendergast (2002) also reviews some mixed evidence for risk-incentive relationship in the areas other than executive compensation.
} 
for uncertainties help partially (if not fully) restore the negative risk-incentive relation predicted by the standard agency theories. In our empirical analysis, without including profitability uncertainty variables, the regression coefficient on return volatility, a risk measure, is often insignificant or positive. Once we include profitability uncertainty proxies, the coefficient on stock return volatility generally becomes negative or less positive.

The rest of this paper is organized as follows. Section 2 presents the model and its prediction of the positive relation between profitability uncertainty and incentives. Section 3 conducts empirical analysis and Section 4 concludes the paper. All proofs are in the Appendix.

\section{The Model}

\subsection{The Setting}

We consider a two-period investment model, where the investment consists of capital and (managerial) labor inputs. Investors are risk neutral, and managers are risk averse with CARA preference. We will interpret labor input as the manager's effort. For simplicity, we will assume that moral hazard only exists in the first period, but the firm matures in the second period and therefore is no longer subject to agency issues. Without loss of generality, the risk-free rate is set to zero.

The output in each period, before the investment cost, is modeled as (similar to the $A K$ technology in the investment literature)

$$
y_{t}=\theta\left(K_{t}+L_{t}\right)+\epsilon_{t},
$$

where $K_{t}$ is the capital level at period $t, L_{t}$ is the managerial labor input at period $t$, and $\epsilon_{t} \sim \mathcal{N}\left(0, \sigma_{\epsilon}^{2}\right)$ is the i.i.d. normally distributed random noises. Importantly, $\theta$, which can be interpreted as the project's profitability or marginal productivity, is uncertain. Neither the firm nor the manager can observe the profitability $\theta$ directly, and they will learn $\theta$ along the equilibrium path. At time 0 the common prior about the profitability is 8

$$
\theta \sim \mathcal{N}\left(\theta_{0}, \gamma_{0}\right)
$$

The multiplicative specification $\theta$ and managerial labor input $L$ in the $A K$ technology is important in driving the positive uncertainty-incentive relationship due to the learning-by-doing effect. However, it

\footnotetext{
${ }^{8}$ For purely technical convenience, we assume that $\theta$ can be negative. The results go through if we assume that $\theta$ is lognormal. However, this specification does not add much intuition for the purpose here. Moreover, due to principal's option to abandon the project, $\theta_{0}$ must be reasonably big for the project to be taken. Hence, the probability of a negative $\theta$ is small.
} 
is worth pointing out that the positive relationship may well arise under an additive specification (e.g., DeMarzo and Sannikov (2008)). We use the multiplicative framework in the present paper to illustrate the role of learning-by-doing effect (i.e., implementing a higher effort can reduce the posterior variance of the unknown profitability parameter $\theta$ ).

At the beginning of period 1, the firm faces a binary decision of whether to make the investment or not, and if investment occurs, the lump sum investment $K_{1}$ is normalized to 1 . Investors will only make the initial investment if their total expected value from this project exceeds their outside option, which is normalized to zero. Hence, $\left(\theta_{0}, \gamma_{0}\right)$ must be sufficiently favorable for the project to be adopted.

Given the capital level $K_{1}$, investors hire a manager to provide labor input $L_{1}$. Unfortunately, the labor input $L_{1}$ (which can be interpreted as managerial effort) is unobservable, therefore due to moral hazard issues investors offer the manager a compensation contract for proper incentives. For simplicity, we focus on the space of linear contracts, where the wage contract $w_{1}$ takes the following form:

$$
w_{1}(y ; \alpha, \beta) \equiv \alpha+\beta y_{1}=\alpha+\beta\left(\theta\left(1+L_{1}\right)+\epsilon_{1}\right)
$$

Here, $\alpha$ is the fixed salary, and $\beta$ is the incentive. The monetary cost for the manager's labor $L_{1}$ is $\frac{l}{2} L_{1}^{2}$, where $l>0$ is a positive constant. Therefore, the manager's utility by accepting the contract $w_{1}(y ; \alpha, \beta)$ and working $L_{1}$ is given by

$$
U\left(L_{1}, w_{1}\right)=-\exp \left(-a\left(w_{1}-\frac{l}{2} L_{1}^{2}\right)\right)=-\exp \left(-a\left(\alpha+\beta y_{1}-\frac{l}{2} L_{1}^{2}\right)\right),
$$

where $a>0$ is the manager's risk-aversion coefficient. We will study the manager's effort choice given the contract $w_{1}$, which is summarized by $(\alpha, \beta)$. Finally, the manager has a reservation utility of $\widehat{U}$ at time 0 , which is normalized to -1 without loss of generality.

Suppose that the firm induces a labor input of $L_{1}^{*}$ from the period 1 manager. At the second period the firm makes capital investment and labor investment based on the updated posterior of project profitability $\theta_{1}$. For period-2 labor investment $L_{2}$, we simply assume that they hire another manager with the same cost function $\frac{l}{2} L_{2}^{2}$, and for simplicity, we assume away any agency problem at period 2 (as the firm's operation becomes more like a routine). ${ }^{9}$ For capital investment, given initial capital level 1 , an investment of $I$ leads

\footnotetext{
${ }^{9}$ The assumption of no agency issue in the second period is innocuous and for convenience only. As long as the period 2 managerial labor input has impact on the learning of profitability of period 3, period 2 incentives (if moral hazard problem
} 


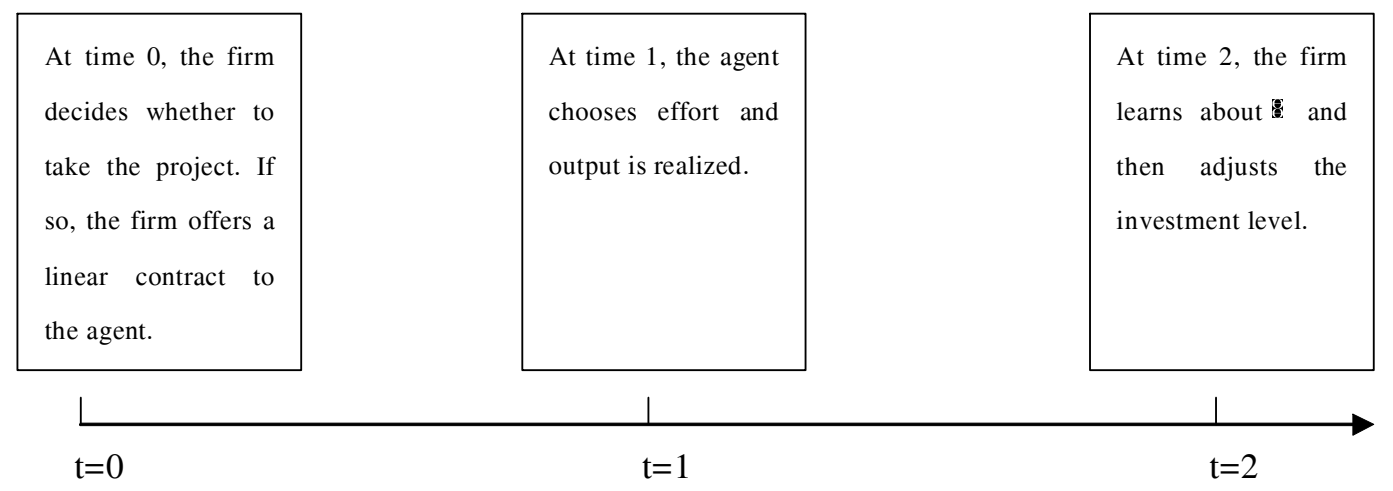

Figure 1: Timeline of the model.

to a new capital level of $1+I$, but incurs a quadratic adjustment cost of $I+\frac{k}{2} I^{2}$, where $k>0$ is a positive constant. As a result, investors at the beginning of period 2 will solve the following problem:

$$
\max _{I, L_{2}} \mathbb{E}\left[\theta\left(1+I+L_{2}\right)+\epsilon_{2}-\frac{1}{2} k I^{2}-I-\frac{l}{2} L_{2}^{2} \mid y_{1}, L_{1}^{*}\right] \text {. }
$$

In summary, the timeline of the model is as follows, as shown in Figure 1. We solve the model backward in the following sections.

1. At the beginning of $t=1$ the firm is deciding whether to take a project with capital normalized to 1. Its outside option is normalized to zero.

2. If the firm decides to take this project, investors hire one manager and offers him a linear contract $w_{1}=\alpha+\beta y_{1}$, where $y_{1}=\theta\left(1+L_{1}\right)+\epsilon_{1}$ is the project's output at period 1 . Therefore the investors' payoff at period 1 is given by

$$
y_{1}-w_{1}-1=\theta\left(1+L_{1}\right)+\epsilon_{1}-\alpha-\beta y_{1}-1
$$

3. Given the outcome $y_{1}$, investors update their belief about $\theta$ based on the prior $\theta \sim \mathcal{N}\left(\theta_{0}, \gamma_{0}\right)$.

still persists) will share the same qualitative feature as period 1 incentives. The important assumption is that the old period 1 manager is replaced by another new manager in period 2, so that the incentive contract is short-term. With long-term employment relationship and endogenous learning, the manager can enjoy some endogenous information rent (as the manager who shirks at period 1 knows that the project actually is better than what investors believe), which makes analysis complicated. See He, Yu, and Wei (2010) for details. 
4. At $t=2$, the firm can make the capital investment $I$ and labor investment $L_{2}$, so that $y_{2}=$ $\theta\left(1+I+L_{2}\right)+\epsilon_{2}$. The second period payoff is

$$
\theta\left(1+I+L_{2}\right)+\epsilon_{2}-I-\frac{k}{2} I^{2}-\frac{l}{2} L_{2}^{2}
$$

\subsection{Learning and Investing in Period 2}

Immediately after observing $y_{1}$ at period 1 , investors update their belief about $\theta$. Given the optimal labor input $L_{1}^{*}$ implemented by the incentive contract at period 1, Bayes' rule implies that the posterior of the project's profitability is characterized by the posterior mean and posterior variance:

$$
\begin{aligned}
\theta_{1} & \equiv \mathbb{E}\left[\theta \mid y_{1}, L_{1}^{*}\right]=\theta_{0}+\frac{\gamma_{1}\left(1+L_{1}^{*}\right)}{\sigma_{\epsilon}^{2}}\left[y_{1}-\theta_{0}\left(1+L_{1}^{*}\right)\right] \\
\gamma_{1} & \equiv \operatorname{Var}\left[\theta \mid y_{1}, L_{1}^{*}\right]=\frac{\gamma_{0} \sigma_{\epsilon}^{2}}{\sigma_{\epsilon}^{2}+\gamma_{0}\left(1+L_{1}^{*}\right)^{2}} .
\end{aligned}
$$

Intuitively, $y_{1}-\theta_{0}\left(1+L_{1}^{*}\right)$ represents an unexpected shock from the output. Then if investors observes a positive unexpected shock $y_{1}-\theta_{0}\left(1+L_{1}^{*}\right)>0$, which serves a positive signal to the project profitability $\theta$, then as in Eq. (3) they should update the long-term profitability $\theta_{1}$ upwards.

As we will see shortly, given the period 1 output information, the profitability estimate $\theta_{1}$ guides the firm's investment decision at period 2. The posterior variance $\gamma_{1}$ in Eq. (4), which measures the precision of profitability estimate $\theta_{1}$, directly determines the investment efficiency at period 2. Moreover, it is important to stress that the posterior variance $\gamma_{1}$ negatively depends on $L_{1}^{*}$, thanks to the multiplicative structure in Eq. (1). Otherwise, a greater investment in $K_{1}$ or $L_{1}$ has no impact on the informativeness of the signal $y_{1}$ in learning the profitability $\theta$.

At period 2 the firm makes capital investment and labor investment to solve the following problem:

$$
\begin{aligned}
V_{2}\left(\theta_{1}\right) & \equiv \max _{I, L_{2}} \mathbb{E}\left[\theta\left(1+I+L_{2}\right)+\epsilon_{2}-I-\frac{1}{2} k I^{2}-\frac{l}{2} L_{2}^{2} \mid y_{1}, L_{1}^{*}\right], \\
& =\theta_{1}+\frac{\left(\theta_{1}-1\right)^{2}}{2 k}+\frac{\theta_{1}^{2}}{2 l}
\end{aligned}
$$

where we have expressed the investors' period 2 value $V_{2}\left(\theta_{1}\right)$ as a function of the period 1 posterior mean $\theta_{1}$. For instance, had the investors perfectly known $\theta$, they would have chosen the investment level $\frac{\theta-1}{k}$. Due to imperfect information, the optimal investment $I^{*}=\frac{\theta_{1}-1}{k}$ deviates from the optimal level $\frac{\theta-1}{k}$ in the full-information setting, and the difference has a variance of $\gamma_{1} / k^{2}$. 
Standing at time 0 , the time- 0 expected payoff from period 2 is given by

$$
\mathbb{E}\left[V_{2}\left(\theta_{1}\right)\right]=\theta_{0}+\frac{\left(1-\theta_{0}\right)^{2}}{2 k}+\frac{\theta_{0}^{2}}{2 l}+\frac{l+k}{2 k l}\left(\gamma_{0}-\gamma_{1}\right)
$$

In other words, investors' expected value in period 2 is decreasing in $\gamma_{1}$, i.e., the posterior variance of the unobserved profitability $\theta$. Intuitively, the lower the posterior variance $\gamma_{1}$, the more precise the estimate of the profitability $\theta$, and the more efficient the second period investment. Moreover, from Eq. (4), $\gamma_{1}$ decreases with effort $L_{1}^{*}$. This important observation implies that, when raising the incentive in the first period, there is more information content in period 1 output $y_{1}$, and hence investors learn more about the unobservable profitability $\theta$. As we will elaborate on in the next section, this learning-by-doing mechanism is the key in driving our result.

\subsection{Optimal Contracting in Period 1}

We now solve the model backward for Stages 2 and 1. At Stage 2, i.e., after the firm decides to take the project and hires a manager, we solve for the optimal linear contract, and in turn the firm's value from this project. Then at Stage 1, the firm will take the project if and only if this value exceeds 0 .

At Stage 2, investors offer a linear contract $w_{1}=\alpha+\beta y_{1}$ to implement the optimal labor (effort) $L_{1}^{*}$, and the optimal contract maximizes their expected total value (including both periods' cash flows):

$$
\max _{\alpha, \beta, L_{1}^{*}} \mathbb{E}\left[y_{1}-w_{1}-1+V_{2}\left(\theta_{1}\right)\right]
$$

subject to the manager's incentive compatibility and the participation constraints:

$$
L_{1}^{*}=\arg \max _{L_{1}} \mathbb{E}\left[-\exp \left(-a\left(w_{1}-\frac{l}{2} L_{1}^{2}\right)\right)\right], \text { and } \mathbb{E}\left[-\exp \left(-a\left(w_{1}-\frac{l}{2} L_{1}^{2}\right)\right)\right] \geq \widehat{U} .
$$

The following lemma gives the manager's optimal labor (effort) choice in response to the incentive contract summarized by $(\alpha, \beta)$ :

Lemma 1 A contract $w_{1}=\alpha+\beta y_{1}$ implements labor $L_{1}^{*}$ and satisfies the manager's participation constraint if and only if

$$
L_{1}^{*}=\frac{\beta\left(\theta_{0}-a \gamma_{0} \beta\right)}{l+a \gamma_{0} \beta^{2}}
$$

and

$$
\alpha=-\beta \theta_{0} \frac{l+\theta_{0} \beta}{l+a \gamma_{0} \beta^{2}}-\frac{1}{2} \frac{\beta^{2}\left(\theta_{0}^{2}+a l \gamma_{0}\right)}{l+a \gamma_{0} \beta^{2}}+\frac{1}{2} a \sigma_{\epsilon}^{2} \beta^{2}
$$




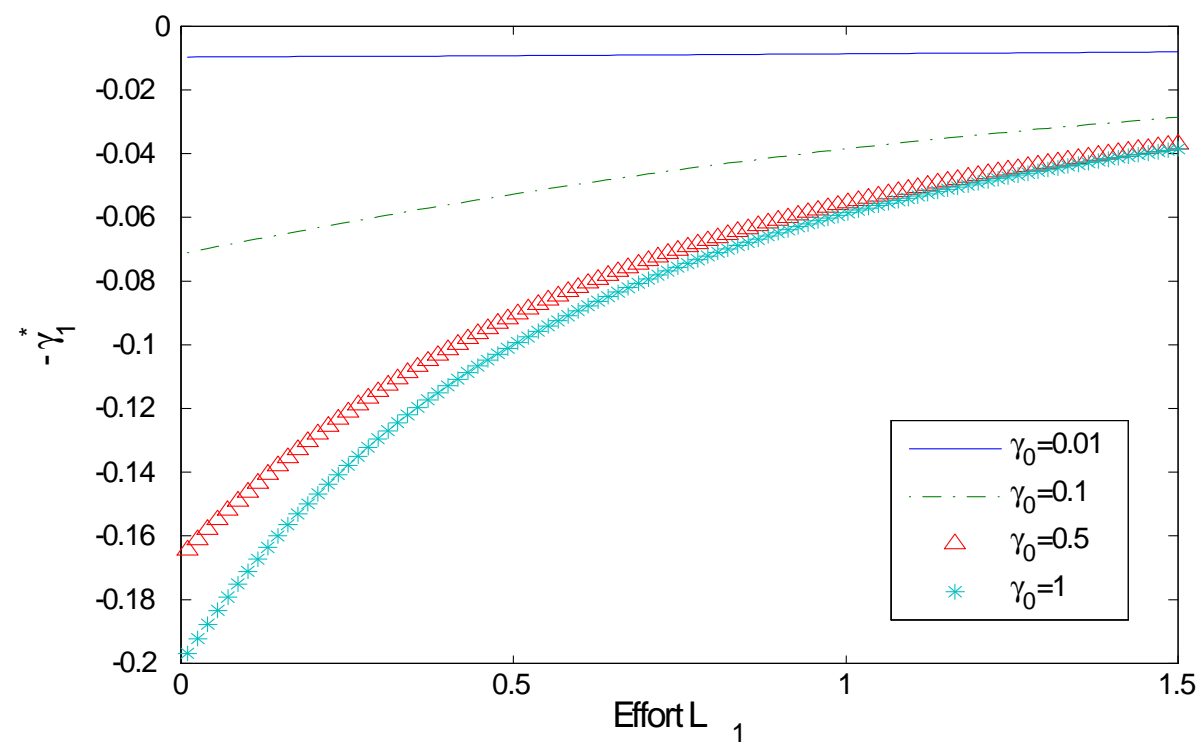

Figure 2: The negative posterior variance $-\gamma_{1}$ as a function of effort in period 1 for different values of $\gamma_{0}$.

Essentially, Lemma 1 establishes an important link between the implemented labor $L_{1}^{*}$ and the incentive loadings $\beta$ in any incentive-compatible contracts, which allows the firm to choose implemented $L_{1}^{*}$ (in turn the contract parameters $\alpha$ and $\beta$ ) to maximize its value function. In light of Lemma 1, we can replace the incentive compatibility and the participation constraints in the investors' problem by Eq. (7) and Eq. (8). Together with Eq. (5), Eq. (3), and Eq. (4), we can rewrite the investors' problem in Eq. (6) as (for details, see the proof of Lemma 1 in Appendix):

$$
\begin{aligned}
L_{1}^{*} & \in \underset{L_{1}}{\arg \max _{0}}\left[\theta_{0}\left(L_{1}+1\right)-\frac{L_{1}^{2} l}{2}-\frac{a}{2}\left(\gamma_{0}\left(1+L_{1}\right)^{2}+\sigma_{\epsilon}^{2}\right) \beta^{2}+\frac{k+l}{2 k l} \frac{\gamma_{0}^{2}\left(1+L_{1}\right)^{2}}{\sigma_{\epsilon}^{2}+\gamma_{0}\left(1+L_{1}\right)^{2}}\right] \\
\text { s.t. } L_{1} & =\frac{\beta\left(\theta_{0}-a \gamma_{0} \beta\right)}{l+a \gamma_{0} \beta^{2}} .
\end{aligned}
$$

The first term in the investors' value function is the expected first period output, the second term is the labor cost, the third term is the manager's risk compensation, and the last term is the firm's period 2 continuation value. Once we derive the optimal effort level $L_{1}^{*}$, the optimal contract (i.e., $\alpha^{*}$, and $\beta^{*}$ ) can be completely specified by Eq. (7) and Eq. (8).

\subsection{Positive Incentive-Uncertainty Relation}

In our model, learning could induce a positive relation between incentives and uncertainty. This result is rooted in the fact that investors' expected value of period 2 value, $\mathbb{E}_{0}\left[V_{2}\left(\theta_{1}\right)\right]$, depends on learning about 
profitability $\theta$ from period-1 output $y_{1}$. As indicated by Eq. (5), maximizing $\mathbb{E}_{0}\left[V_{2}\left(\theta_{1}\right)\right]$ is equivalent to minimizing the posterior variance of $\theta$, i.e., $\gamma_{1}$. Because $L_{1}$ is multiplicative with $\theta$ in the signal $y_{1}$ as in (1), implementing a higher effort $L_{1}$ raises the informativeness of the period 1 signal $y_{1}$, or equivalently, reduces the posterior variance $\gamma_{1}$. Essentially, this mechanism shares the similar spirit to the learning-bydoing literature (e.g., Jovanovic and Lach (1989), Jovanovic and Nyarko (1996), and Johnson (2007)). For example, Johnson (2007) shows that when there is uncertainty about firms' production function, firms tend to overinvest due to the desire to learn about the unknown production function.

Presumably, this learning-by-doing effect is stronger in a more uncertain environment (i.e., a larger $\gamma_{0}$ ). This is because starting with a larger $\gamma_{0}$, the reduction of the posterior variance will be more significant, which results in a greater benefit of inducing a higher effort. That is, based on Eq. (4), we have

$$
\frac{\partial^{2}\left(-\gamma_{1}\right)}{\partial L_{1}^{*} \partial \gamma_{0}}>0
$$

In Figure 2, we plot $-\gamma_{1}^{*}$ as a function of effort $L_{1}$ for different levels of $\gamma_{0}$. As we can see, when $\gamma_{0}$ increases, the marginal benefit of raising effort $L_{1}$ becomes greater. To implement a higher effort, a greater incentive $\beta^{*}$ is needed, which results in a positive relation between uncertainty and incentives.

In Proposition 1 we formally prove the existence of such a positive uncertainty-incentive relation when the manager is sufficiently risk tolerant. Notice that high uncertainty also implies a greater incentive provision cost, since uncertainty raises the risk that the manager is bearing. This is the reason why we require the manager to be sufficiently risk tolerant.

Proposition 1 For sufficiently small risk aversion coefficient a, a positive relation exists between $\beta^{*}$ and $\gamma_{0}$, i.e., $\frac{d \beta^{*}}{d \gamma_{0}}>0$.

Figure 3 plots the incentive $\beta^{*}$ as a function of both uncertainty $\gamma_{0}$ and risk $\sigma_{\epsilon}^{2}$. Here, we vary the profitability uncertainty $\gamma_{0}$ in the left panels (Panel A and C) and the cash flow risk $\sigma_{\epsilon}^{2}$ in the right panels (Panel B and D). We set absolute risk aversion $a=0.01$ for the top two panels. ${ }^{10}$ In Panel A (B), we vary $\gamma_{0}\left(\sigma_{\epsilon}^{2}\right)$ from 0 to 0.25 . Panel B gives the traditional negative trade-off between risk $\sigma_{\epsilon}^{2}$ and incentives $\beta^{*}$. However, as predicted by Proposition 1, Panel A gives a positive relation between profitability uncertainty $\gamma_{0}$ and incentive $\beta^{*}$.

\footnotetext{
${ }^{10}$ Given CEOs are relatively wealthy, it is reasonable to choose a small absolute risk aversion coefficient since $a \times W e a l t h$ is the relative risk aversion coefficient. As suggested by Proposition 1, if we raise the risk aversion coefficient $a$, the relation between parameter uncertainty and incentives can be reversed. However, for a reasonably small risk aversion coefficient, we generally obtain a positive relation between uncertainty and incentives.
} 

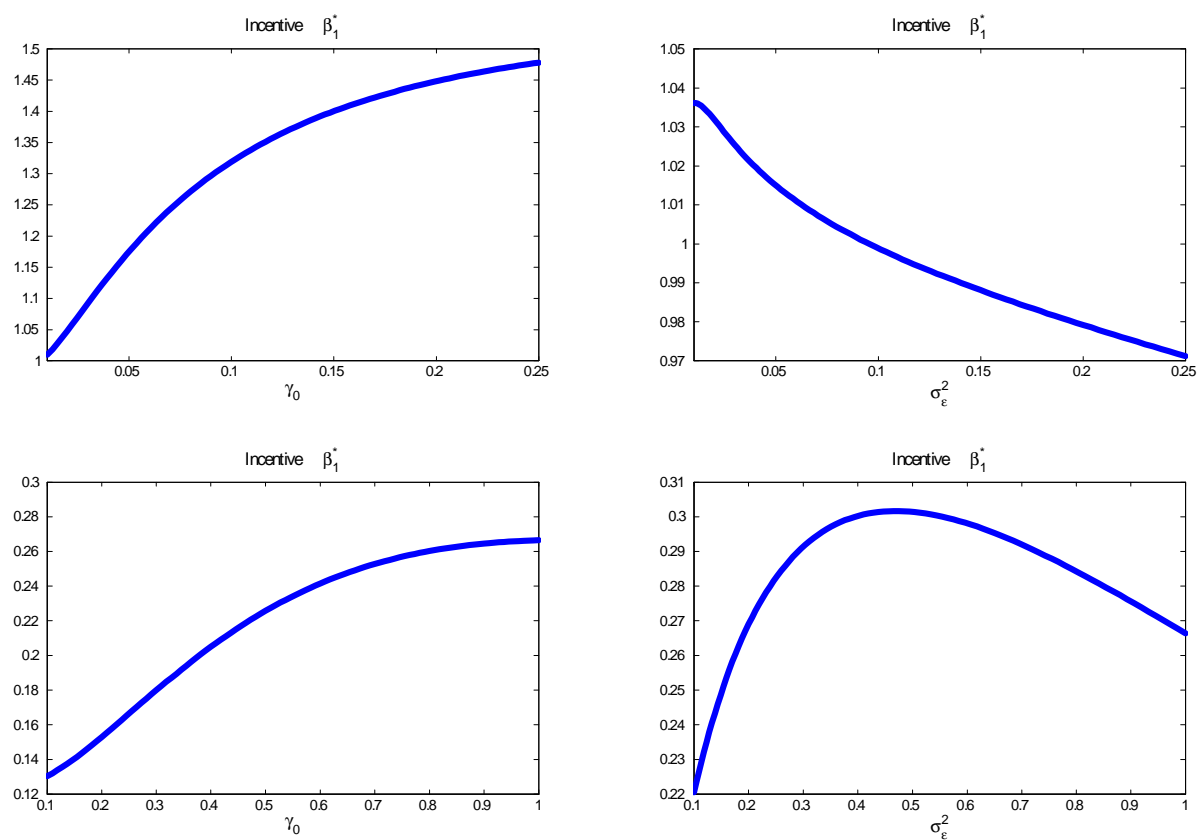

Figure 3: Incentives $\beta^{*}$ as functions of $\gamma_{0}$ (left panels $\mathrm{A}$ and $\mathrm{C}$ ) and $\sigma_{\epsilon}$ (right panels $\mathrm{B}$ and D). The baseline parameters are $l=20 ; k=0.05 ; \theta_{0}=1.2$. In Panel A, we set $a=0.01$ and $\sigma_{\epsilon}=0.25$. In Panel B, we set $a=0.01$ and $\gamma_{0}=0.01$. In Panel C, we set $a=0.5$ and $\sigma_{\epsilon}=1$. For Panel D, we set $a=0.5$ and $\gamma_{0}=1$.

In the top two panels, the model implied incentive $\beta^{*}$ is relatively high. When we raise the cash flow risk $\sigma_{\epsilon}^{2}$, parameter uncertainty $\gamma_{0}$, and absolute risk aversion $a$, the model-implied incentive $\beta^{*}$ can be reduced to a much more reasonable range as shown in the bottom two panels $\mathrm{C}$ and $\mathrm{D}$. When we set $a=0.5$, there is still a positive relation between uncertainty and incentives. However, the traditional tradeoff between risk and incentive is now hump shaped. The driving force for this hump shape risk-incentive relation is again the "learning-by-doing" effect. Notice that investors would like to reduce the posterior variance

$$
\gamma_{1}=\frac{\gamma_{0} \sigma_{\epsilon}^{2}}{\sigma_{\epsilon}^{2}+\gamma_{0}\left(1+L_{1}^{*}\right)^{2}},
$$

and one can easily show that $\frac{\partial^{2}\left(-\gamma_{1}\right)}{\partial L_{1}^{*} \partial \sigma_{\epsilon}^{2}} \leq 0$ when $\sigma_{\epsilon}^{2} \geq \gamma_{0}\left(1+L_{1}^{*}\right)^{2}{ }^{11}$ In this case, the information-noise ratio is low and there is a lot of room for learning. In this situation, the marginal benefit of expediting learning (through raising labor input) is positively related to information-to-noise ratio. Hence, a greater $\sigma_{\epsilon}^{2}$

\footnotetext{
${ }^{11}$ We have $\frac{\partial\left(-\gamma_{1}\right)}{\partial \sigma_{\epsilon}^{2}}=-\frac{\gamma_{0}^{2}\left(1+L_{1}^{*}\right)^{2}}{\left(\sigma_{\epsilon}^{2}+\gamma_{0}\left(1+L_{1}^{*}\right)^{2}\right)^{2}}=-\frac{\gamma_{0}^{2}}{\left(\frac{\sigma_{\epsilon}^{2}}{1+L_{1}^{*}}+\gamma_{0}\left(1+L_{1}^{*}\right)\right)^{2}}$, therefore $\frac{\partial^{2}\left(-\gamma_{1}\right)}{\partial L_{1}^{*} \sigma_{\epsilon}^{2}}$ depends on the sign of $\frac{\partial\left[\frac{\sigma_{\epsilon}^{2}}{1+L}+\gamma_{0}\left(1+L_{1}^{*}\right)\right]}{\partial L_{1}^{*}}=-\frac{\sigma_{\epsilon}^{2}}{\left(1+L_{1}^{*}\right)^{2}}+\gamma_{0}$.
} 
lowers the marginal benefit $\frac{\partial\left(-\gamma_{1}\right)}{\partial L_{1}^{*}}$ when raising labor input. On the other hand, when $\sigma_{\epsilon}^{2}<\gamma_{0}\left(1+L_{1}^{*}\right)^{2}$,

we have $\frac{\partial^{2}\left(-\gamma_{1}\right)}{\partial L_{1}^{*} \partial \sigma_{\epsilon}^{2}}>0$. In this case, the information-to-noise ratio is sufficiently high and hence, we already learned a lot about the profitability $\theta$. As a result the marginal learning benefit by increasing effort is low. However, for a greater $\sigma_{\epsilon}^{2}$, the information-to-noise ratio is reduced. As a result, there is more room to learn, and consequently a higher marginal benefit from learning. Taken together, there is a potential positive relation between incentives and risk due to learning, and this learning effect might dominate the traditional negative risk-incentive trade-off. In sum, in contrast to the standard principal-agent setting, our model predicts a non-monotonic relation between risk and incentives.

In a nutshell, our multiplicative model not only predicts a positive relation between uncertainty and incentives for small risk aversion coefficients, but also suggests that there is not necessarily a clear-cut relationship between risk and incentives. Hence, our model provides another potential explanation why it is difficult to identify a negative risk-incentive trade-off in the data. However, we by no means use our simple model to quantitatively match the (moments of) incentives observed in the data. Instead, we simply use it to highlight the idea that learning on unobservable profitability can lead to a positive relation between uncertainty and incentives.

\section{Empirical Analysis}

In this section, we empirically test the prediction of a positive relation between uncertainty and incentives. We also investigate how this positive relation affects the traditional trade-off between risk and incentives. Below in Section 3.1, we describe our data, incentive and risk measures, and profitability uncertainty proxies. We then provide regression results in Section 3.2.

\subsection{Data, Variables, and Summary Statistics}

\subsubsection{Data and Sample Selection}

Our sample consists of a manager-firm matched panel dataset from 1992 to 2008. This dataset allows us to track through time the highest paid executives in firms covered by ExecuComp. We merge the manager-level ExecuComp data with the firm-level annual accounting variables from Compustat, stock returns from CRSP, corporate board information from RiskMetrics, and analyst forecast information from IBES. We then remove the observations with incomplete data. We also winsorize the continuous variables that present obvious outliers, by replacing the extreme values with the $1 \%$ and $99 \%$ percentile values. Our 
full sample includes 2,441 firms and 25,999 top executives who have worked for these companies, and the main regressions are estimated based on this full sample.

\subsubsection{Pay-Performance Sensitivity}

The dependent variable in the paper is pay-performance sensitivity (PPS), a standard variable used in the literature to measure managerial incentives. The literature on executive compensation typically employs two measures of PPS. The first measure, the dollar-to-dollar measure (PPS1), is equal to the dollar change in stock and option holdings for a one dollar change in firm value (see, e.g., Aggarwal and Samwick

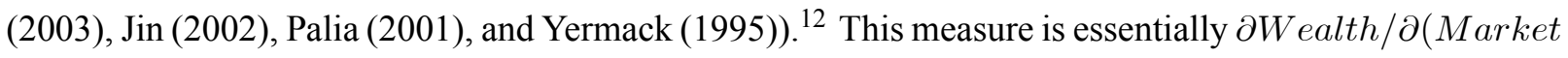
Value) (where Wealth is the CEO's wealth) and is also called value-sensitivity or share of the money in Becker (2006). Another measure, the dollar-to-percentage measure (PPS2), is equal to the dollar change in stock and option holdings for a one percent change in firm value (Core and Guay (2002)). The PPS2 measure is equal to $\partial W$ ealth $/ \partial($ Return $)$ and is also referred to as return-sensitivity or money at stake in Becker (2006).

Baker and Hall (2004) mention that both PPS measures may be appropriate, depending on how CEO actions are assumed to affect firm value. When CEO actions primarily affect firm dollar returns and have constant dollar effects across firms of different sizes (such as perquisite consumption through the purchase of a corporate jet), the appropriate measure of CEO incentives is dollar-to-dollar. In contrast, when CEO actions have an impact proportional to firm size and thus primarily affect firm percentage returns (such as the implementation of firm strategy), the appropriate measure of CEO incentives is dollar-to-percentage. Baker and Hall (2004) estimate the marginal product of CEO effort and find that neither polar case assumption is correct: the marginal product of CEO effort scales with firm size in varying degrees. They interpret the results as evidence that CEOs participate in a range of activities. As a result, similar to Becker (2006) and Core and Guay (1999), we use both measures of PPS in our empirical analysis.

The two PPS measures mentioned above are standard measures employed in the extant literature, which include Aggarwal and Samwick (2003), Becker (2006), Core and Guay (2002), etc. In addition to these two direct measures of incentives, some empirical studies use a regression approach to obtain PPS. In this

\footnotetext{
${ }^{12}$ Jensen and Murphy (1990) measure PPS as the change in a CEO's total wealth resulting from a \$1000 increase in shareholder value. The total wealth includes financial wealth and capitalized future labor income. Hall and Liebman (1998) argue that changes in CEO's financial wealth account for nearly all of the PPS value. Furthermore, financial wealth can be measured relatively precisely compared to capitalized future labor income. Therefore, we focus our analysis on PPS calculated from a CEO's financial wealth.
} 
approach, executives' wealth is regressed on firm performance and other firm characteristic variables, and the coefficient on firm performance is interpreted as the pay-performance sensitivity (see e.g., Aggarwal and Samwick (1999), Garvey and Milbourn (2003), and Jensen and Murphy (1990)). Differing from such regression technique that derives a single estimate of the average pay-performance link, the direct approach calculates PPS1 and PPS2 for each individual executive and obtains a distribution of incentives. We also replicate our empirical analysis using the PPS obtained from the regression approach and we achieve essentially the same results. ${ }^{13}$

\subsubsection{Empirical Proxies for Profitability Uncertainty}

The primary explanatory variables of interest in the paper are five profitability uncertainty variables. These variables have been used in the existing literature (Pastor and Veronesi, 2003; Korteweg and Polson, 2009) as proxies for profitability uncertainty. Below we explain the five proxies, and we also include the detailed definitions of these variables in Appendix B. It is worth noting that the results of the paper should be interpreted with the following points in mind. First, the uncertainty proxies are not perfect; they could reflect firm characteristics other than profitability uncertainty. It is, therefore, important to investigate an array of uncertainty variables commonly used in the literature and see whether all these variables give consistent results. Second, some of the uncertainty variables we use are positively correlated with firm volatility; others are negatively correlated with volatility. Examining all the different uncertainty variables will help us separate the role of uncertainty from that of volatility. Furthermore, we do not use firm size as an uncertainty proxy, although it is proposed by such literature as Korteweg and Polson (2009). There exists a strong empirical relation between size and PPS; that is, firm size is negatively correlated with PPS1 and positively correlated with PPS2 (e.g., Edmans, et al., 2009). The literature has proposed various explanations for this pattern, and therefore size may not be a clean profitability uncertainty variable for our purpose. ${ }^{14}$ We do, however, include firm size in all our regressions as a control variable to capture the

\footnotetext{
${ }^{13}$ Using the regression approach, the coefficient of the cross term of firm performance and variable X can be interpreted as the marginal effect of $X$ on PPS. We find that the coefficients of the cross terms of firm performance and the uncertainty variables are consistent with our expectations. We also find that the coefficient of the cross term of firm performance and volatility becomes generally negative when the uncertainty variables are captured.

${ }^{14}$ For instance, in the Holmstrom and Milgrom's CARA-Normal framework, risk is measured in dollar returns. Then dollar-todollar PPS1 should be lower for larger firms with greater dollar variances in output. For the dollar-to-percentage PPS2 meaure, the matching model in Gabaix and Landier (2008) suggests that pay increases with firm size. Since part of compensation is in variable pay, it suggests that PPS2 is positively correlated with firm size.
} 
size effect. ${ }^{15}$

Natural log of firm age The first proxy that we employ is firm age. Previous studies such as Pastor and Veronesi (2003) and Korteweg and Polson (2009) use firm age as a proxy for profitability uncertainty. Uncertainty declines over a firm's lifetime due to learning, and younger firms have higher uncertainty. Following Pastor and Veronesi (2003), we consider each firm as "born" in the year of its first appearance in the CRSP database. Specifically, we obtain the first occurrence of a valid stock price on CRSP, as well as the first occurrence of a valid market value in the CRSP/COMPUSTAT database, and take the earlier of the two. The firm's age is assigned the value of one in the year in which the firm is born and increases by one in each subsequent year. As in Pastor and Veronesi (2003), we take the natural log of firm age. $\log ($ age $)$ is concave in firm's plain age, and this is to capture the idea that regarding uncertainty, one year of age should matter more for young firms than for old firms. ${ }^{16}$

Earnings response coefficient (ERC) In constructing our second proxy for profitability uncertainty, we follow Pastor et al. (2009) and Cremers and Yan (2010), and use the stock price reaction to earnings announcements (i.e., earnings response coefficient or briefly, ERC). Intuitively, investors who are more uncertain about the profitability of a company should respond more strongly to earnings surprises. Pastor et al. (2009) propose two ERC measures (ERC1 and ERC2). ERC1 is the average of a firm's previous 12 stock price reactions to quarterly earnings surprises, and ERC2 is the negative of the regression slope of the firm's last 20 quarterly earnings surprises on its abnormal stock returns around earnings announcements. Appendix B provides more details on the ERC variable. We report in the paper the results from using the ERC1 variable and the results from the ERC2 variable are similar and available upon request. As noted in Pastor et al. (2009), the ERC measure is ideal to separate uncertainty from volatility because ERC is high when uncertainty is high and when earnings volatility is low. When realized earnings are more precise,

\footnotetext{
${ }^{15} \mathrm{We}$ also decide not to use some other uncertainty proxies in the literature. Baker and Wurgler (2006) provide some proxies for hard-to-value stocks. Besides the variables we mention above, they mention that non-dividend-paying stocks are harder to value than dividend-paying stocks because the value of a firm with stable dividends is less subjective. As a result, dividend-paying firms possibly have lower uncertainty and thus may be related to lower incentives. We do see a consistent negative association between the dividend-paying indicator and PPS in our regressions. An alternative explanation of the negative association is that firms with cash constraints (such as non-dividend-paying companies) might prefer restricted stock and options over cash compensation. As a result, a higher PPS is more likely to be observed among non-dividend payers (Jin (2002) and Yermack (1995)). We include the dividend-paying indicator as a control variable in all model specifications.

${ }^{16}$ Pastor and Veronesi (2003) also use the negative of the reciprocal of one plus the firm age. Using this measure, we find similar results.
} 
investors would react more to earnings surprises, leading to a higher value of ERC. The shortcoming of the ERC measure is its measurement error. As a result, we also incorporate other empirical proxies of uncertainty in the analysis.

Market-to-book ratio The third proxy for profitability uncertainty is the market-to-book ratio, which equals market value of equity plus the book value of debt, divided by total assets. Pastor and Veronesi (2003) show that aging in the life of a firm is accompanied by a decrease in the market-to-book ratio. According to Korteweg and Polson (2009), the market-to-book ratio is a proxy for firm growth opportunities, and such opportunities are inherently more difficult to value than the assets in place. As a result, the market-to-book ratio increases with the uncertainty about firm profitability. We acknowledge that the market-to-book ratio may capture firm growth and other characteristics in addition to uncertainty. An investigation of the market-to-book ratio may not be a direct test of the impact of uncertainty on incentives. It is thus important to also examine a variety of other uncertainty proxies and see whether all these variables give consistent results. Hence, our results need to be interpreted with this point in mind.

Tangibility The fourth proxy is tangibility. Korteweg and Polson (2009) mention that firms with more tangible assets (property, plant, and equipment) are easier to value and thus are related to lower profitability uncertainty. We use net property, plant, and equipment scaled by firm total assets to measure tangibility.

Analyst forecast error We also construct an analyst forecast error variable as a proxy of profitability uncertainty. Based on Bae et al. (2008) and Lang and Lundholm (1996), for each specific company in each fiscal year, we first obtain the absolute value of the forecast error made by each analyst, where forecast errors are defined as the difference between the forecast value and the actual value of earnings per share. We then use the median value of these absolute forecast errors, scaled by the absolute value of the actual EPS. Using the mean value of the absolute forecast errors gives similar results. ${ }^{17}$

\footnotetext{
${ }^{17}$ Another widely used measure based on IBES data is analysts' forecast dispersion, which usually proxies for potential disagreement in the market. The difference between forecast dispersion and forecast error is that the latter considers the distance between EPS forecast and actual EPS, while the former considers the distance between EPS forecast and the mean forecast among analysts. The forecast error variable better captures profitability uncertainty studied in this paper. Consider the situation where two analysts issued the same EPS forecast of $\$ 5$, and the actual EPS turns out to be $\$ 3$. Then in this example the forecast error will be 2 (which might result from large uncertainty), but the forecast dispersion is just 0 .
} 


\subsubsection{The Risk Variable}

Similar to the literature that tests the relation between risk and incentives, we include stock return volatility as a measure of risk in our regression analysis. As mentioned earlier, existing theories predict a negative relation between risk and incentives, but the empirical evidence on this aspect is inconclusive. Our paper re-examines this issue empirically, with uncertainty variables being included in the empirical specification. We measure stock return volatility as the standard deviation of daily log (percentage) returns over the past five years, which is then annualized by multiplying by the square root of 254 (Yermack (1995) and Palia (2001)). We also use the percentage rank of stock dollar return variance (Aggarwal and Samwick (1999, 2002, 2003); Garvey and Milbourn (2003); and Jin (2002)) in the empirical analysis, we obtain essentially the same results.

\subsubsection{Control Variables}

In the regressions, we include various control variables that could potentially affect the incentives provided by a firm to its managers. These control variables have been used in the empirical literature on the determinants of managerial incentives (Aggarwal and Samwick (2003); Core et al. (1999); Jin (2002); Palia (2001); etc.). As mentioned at the beginning of Section 3.1.3, since there is well-established empirical pattern between incentives and firm size, we first include firm size as a control. Following the literature, we also include profitability, the ratio of capital expenditure to total assets, advertising expenses scaled by total assets, a dummy variable that is set to one whenever advertising expenses are missing, firm leverage, and dividend payout indicator. We further control for corporate governance variables, which include the CEO chair indicator and the proportion of inside directors in the board. Manager-level variables, such as $\log$ (tenure), the CEO indicator, and the female indicator, are also controlled in the regressions. Finally, year and industry effects are included to capture the time and industrial differences in the level of managerial incentives. The detailed definitions of all the variables used in the paper are described in Appendix B.

\subsubsection{Summary Statistics and Correlations between Variables}

Table 1 contains summary statistics of the variables used in the regression analysis. The average (median) dollar-to-dollar measure of PPS is $1.13 \%(0.22 \%)$, suggesting that the average (median) dollar change in the sample executives' stock and option holdings for a one thousand dollar change in firm value is $\$ 11.3$ 
(\$2.2). The summary statistics on the dollar-to-percentage measure of PPS show that the average (median) dollar change in the executives' stock and option holdings for a 1\% change in firm (equity) value is $\$ 168.61$ (\$27.97) thousand. These summary numbers are consistent with those provided in the empirical literature such as Core and Guay (1999), Palia (2001), and Yermack (1995). The statistics also imply a positive skewness in PPS, with a few companies having very high incentives.

The average, median, minimum, and maximum age of the sample firms is $26,20,1$, and 84 years, similar to those reported in Pastor and Veronesi (2003). The firms in the sample have an average (median) earnings response coefficient of 4.44 (2.88), market-to-book ratio of 2.08 (1.51), tangibility of $0.29(0.23)$, and total assets of $\$ 6.6(\$ 1.3)$ billion. The average analyst forecast error relative to the actual value is about $16 \%$. In addition, the average (median) annual stock return volatility is $44 \%$ (39\%).

Table 2 examines the pairwise correlations between the variables. The two PPS variables have a correlation coefficient of 0.55 . The PPS 1 variable is negatively correlated with firm age and tangibility, and is positively correlated with the earnings response coefficient (ERC) and the market-to-book ratio. The correlations between PPS2 and firm age are very low; it may be due to the fact that PPS2 is PPS1 times market value of equity, and the negative relation between age and PPS1 is canceled out by the positive relation between age and market value. When we control for firm size in the model, the relation between PPS2 and firm age becomes negative and significant.

Table 2 also shows that the uncertainty proxy variables are correlated with each other, with the correlation between firm age and market to book being -0.23 and the correlation between firm age and tangibility around 0.18 . This indicates that younger firms tend to be the firms with more growth options and lower tangibility ratios. The table also reveals very low correlations between ERC and volatilities and between ERC and firm size. This suggests that ERC serves an ideal proxy variable that separates uncertainty from volatility and firm size. On the other hand, the percentage return volatilities and the dollar return volatilities have opposite signs in correlations with other variables. This is perhaps due to the fact that the dollar return volatility, which equals percentage return volatility multiplied by firm market value, captures the firm size effect. 


\subsection{Empirical Results}

This section uses regression analysis to examine the effect of profitability uncertainty and risk on incentives. The main empirical model is as follows:

$$
\begin{aligned}
\text { PPS } S_{i j t}= & \alpha+\beta_{1}(\text { Uncertainty proxies })_{j, t-1}+\beta_{2}(\text { Risk })_{j, t-1} \\
& +\beta_{3}(\text { Firm characteristics })_{j, t-1}+\beta_{4}(\text { Managerial characteristics })_{i, t-1} \\
& +\beta_{5}(\text { Year indicators })_{t}+\beta_{6}(\text { Industry } \text { indicator })_{j}+\epsilon_{i j t .} .
\end{aligned}
$$

In the equation, we use $i$ to denote manager, $j$ to denote firm, and $t$ to denote year. The dependent variable is the dollar-to-dollar measure (PPS1) and the dollar-to-percentage measure (PPS2) of pay-performance sensitivities. In the OLS regressions, we control for industry effects using two digit SIC indicator variables. In the firm-manager pair fixed effects regressions, we replace industry effects with firm-manager fixed effects in Eq. (9) as the latter absorbs the former. We lag all the explanatory variables by one year to mitigate potential reverse causality issue. We, however, acknowledge that lagging may not fully resolve endogeneity because serial correlations may exist in some explanatory variables. We thus also use the fixed effects model in robustness analysis to deal with the endogeneity problem caused by time-invariant unobservable factors.

\subsubsection{Main Results}

Tables 3 and 4 report the OLS regression results, with Table 3 having PPS1 as the dependent variable and Table 4 having PPS2. The $t$-statistics in these regressions are heteroskedasticity robust and are adjusted for clustering within firms. In both tables, Column (1) does not include any of the five uncertainty variables, Columns (2)-(6) include one of the five uncertainty variables, and Column (7) include all the five uncertainty variables.

Positive uncertainty-incentive relation The results in both Tables 3 and 4 show that firm age is negatively related to incentives (Columns (2) and (7)), indicating that younger firms, i.e., firms with higher uncertainty, are associated with greater managerial incentives. Both the earnings response coefficient (ERC) and the market-to-book ratio are positively associated with the incentive variable. The relation between tangibility and PPS is negative, suggesting that firms that have more tangible assets are associated with lower incentives. Firms with greater analyst forecast errors (that might be due to greater uncertainty) 
are also shown to give higher incentives to executives (although this coefficient is insignificant in the PPS2 regressions in Table 4). All these results indicate a positive relation between profitability uncertainty and incentives, as predicted by our model. This positive relation is not only statistically significant but also economically important. Take Table 3 Column (7) and Table 4 Column (7) as examples. A onestandard-deviation decrease in $\log$ (firm age), which is about 0.97 (i.e., firm age reduces by about 3 years), is associated with an increase of approximately $0.23 \%(=0.97 \times 0.24)$ in PPS1 and $36.16(=0.97 \times 37.28)$ in PPS2. These values are of similar magnitude to that of the sample median level of PPS. Other uncertainty variables have similar economic significance.

Re-examine the risk-incentive relation Controlling for profitability uncertainty can help reveal the negative risk-incentive relation, a key prediction from standard agency theories but with mixed empirical support from existing literature. From the point of view of this paper, the risk proxies used in the previous literature, namely stock volatility and rank of dollar return volatility, could be contaminated by profitability uncertainty. If profitability uncertainty is positively related to incentives, then it is not surprising that previous research, in which the risk proxy captures both the cash flow risk $\sigma_{\epsilon}^{2}$ and the profitability uncertainty $\gamma_{0}$, finds ambiguous risk-incentive relation.

The above reasoning suggests that in revealing the negative risk-incentive relation, it is important to control for uncertainty, as this helps correct for the positive bias potentially caused by omitting relevant variables that are proxies for profitability uncertainty. Our empirical results offer evidence for this implication. In columns (1) of Tables 3 and 4, when we do not include the uncertainty proxies, stock return volatility is positively related to incentives. This result, which seems odd based on the standard agency theory, is actually consistent with the findings in some empirical studies that document a positive relation between volatility and incentives (Prendergast (2002), Core and Guay (1999), and Conyon and Murphy (2000)).

In columns (7) of Tables 3 and 4, when we include the uncertainty variables in the regressions, the relation between volatility and incentives changes from significantly positive to either insignificantly positive in the PPS1 regression, or to insignificantly negative in the PPS2 regression. This pattern generally hold in other specifications considered in Section 3.2.2 for robustness checks. Although our results do not fully restore the significantly negative risk-incentive relation from the data (possibly due to such reasons as endogenous matching between firm risk and CEO's risk appetite, the learning-by-doing effect in Figure 
3 Panel D in this paper, etc.), it should be safe to say that separating profitability uncertainty from cash flow risk is important when empirically examining the negative risk-incentive relation. Our results also indicate that it may be important to separate the effect of profitability uncertainty from that of risk when studying other corporate variables.

Relation between investment volatility and uncertainty In Table 5 we regress the volatility of quarterly investment-to-capital ratio (quarterly capital expenditure scaled by previous quarter-end net property, plant, and equipment, see Cleary (1999) and Kaplan and Zingales (1997)) on the same explanatory variables as in Eq. (9). Under the "learning-by-doing" mechanism in our model, firms with uncertain long-run profitability are offering high-power incentives to their managers for more informative signals in guiding their investment policies. One immediate check of this "learning-by-doing" channel, without involving executive incentives, is to investigate whether firms with higher uncertainty indeed have higher investment volatilities. As expected, both the correlations in Table 2 and the regression in Table 5 show that investment volatility is increasing in the uncertainty proxies, which offers support to our mechanism.

\subsubsection{Robustness Analysis}

This section performs additional analysis to investigate the robustness of our empirical results.

Risk measured as dollar return volatility In addition to measuring firm risk using the variance of stock percentage returns, we attempt a different measure of firm risk: volatility of stock dollar returns. Following Aggarwal and Samwick $(1999,2003)$ and Jin (2002), we use the percentage rank of the variance of dollar returns. According to Aggarwal and Samwick $(1999,2003)$, the use of the percentage ranks deals with potential outliers in the dollar return data and also allows the pay-performance incentives at different points in the distribution of firm risk to be easily compared. ${ }^{18}$ The OLS regression results using the rank of dollar return volatility are reported in Panel A of Table 6. In Column (1), we find that the rank of dollar return volatility is negative and significant. This result is consistent with the findings in the previous studies that use the rank of dollar return volatility as the measure of firm risk (Aggarwal and Samwick (1999, 2002, 2003), Garvey and Milbourn (2003), and Jin (2002)). In Column (2), we include the uncertainty variables in the model. The coefficients of the uncertainty proxy variables have signs that are consistent

\footnotetext{
${ }^{18}$ In the regressions, we also use an alternative transformation of the raw dollar return variance, namely the logarithm of dollar return variance, and we find basically the same results.
} 
with our theoretical prediction. Younger and less tangible growth firms and firms with greater analyst forecast errors are associated with higher incentives. In Column (2), the dollar return volatility continues to be negative and significant after the uncertainty variables are included in the model. In Columns (3) and (4), the dollar-to-percentage PPS is the dependent variable and we continue to find that firms with greater uncertainty provide higher incentives to their executives. The effect of the risk variable is positive and significant when the uncertainty variables are excluded, but the effect becomes negative (although insignificant) when the uncertainty variables are introduced to the model.

Incentives measured as wealth-performance sensitivity Edmans et al. (2009) proposed an alternative incentive measure: scaled wealth-performance sensitivity (WPS). Specifically, this sensitivity measure equals the dollar change in executive wealth for a 100 percentage point change in firm value, divided by annual flow compensation. This incentive measure is similar to the percentage-to-percentage incentives used in Murphy (1985), Gibbons and Murphy (1992), and Rosen (1992), but replaces flow compensation in the numerator of the Murphy (1985) measure with the change in the executives' wealth. By considering the change in wealth, the scaled wealth-performance sensitivity captures the important incentives from changes in the value of previously granted stock and options. In Panel B of Table 6, we perform regressions with the dependent variable being WPS and find that our results remain intact.

Median regressions Aggarwal and Samwick $(1999,2003)$ and Jin (2002) use median regressions to deal with outliers and the right skewness in the compensation data. Following this literature, we use median regressions and report the results in Panel $\mathrm{C}$ of Table 6 (with risk measured by the percentage return volatility) and Panel D of Table 6 (with risk measured by the rank of dollar return volatility). Both tables show that in general, uncertainty is positively related to incentives. When the dollar-to-dollar PPS is the dependent variable, the coefficient of the risk variable becomes less positive in Panel $\mathrm{C}$ and more negative in Panel D if profitability uncertainty is captured in the model (see Columns (1) and (2) of both tables). The dollar-to-percentage PPS regression gives similar results.

Fixed effect regressions In Panel E of Table 6, we run the regressions by adding the firm-manager paired fixed effects. Fixed effects are to deal with potential endogeneity issues. For example, it is possible that some unobservable managerial attributes (e.g., risk aversions) are correlated with the explanatory variables 
such as firm age and at the same time are correlated with the dependent variable, PPS. The firm-manager fixed effect may also capture time-invariant unobservable factors that potentially affect endogenous matching between the firm and the manager (Graham, et al., 2010). We can see from Panel E that our main results remain similar. The coefficients on the profitability uncertainty proxies continue to show a positive relation between profitability uncertainty and incentives.

Other robustness checks Finally, the tables reported so far examine each top executive's incentives. In untabulated analysis, we also examine the CEO incentives only, and the average incentives for top executives in each individual company. The results, omitted for brevity, provide the same implications as those reported here. In all, the empirical results that we obtain offer strong support to our theoretical prediction that profitability uncertainty is positively related to incentives. ${ }^{19}$

\section{Conclusion}

This paper introduces profitability uncertainty into an agency model, and investigates the relation between profitability uncertainty and incentives. Our model predicts a positive uncertainty-incentive relation, in contrast to the negative risk-incentive trade-off obtained in the extant literature. Therefore, it is important to distinguish risk from uncertainty in studying CEO incentives. Using several proxies for profitability uncertainty, we then empirically test and find strong support for our theoretical prediction. Our study suggests that the mixed empirical results from testing the risk-incentive trade-off may be attributable to a positive bias caused by the omission of relevant variables that are proxies for profitability uncertainty.

\section{References}

Aggarwal, Rajesh K., and Andrew A. Samwick, 1999, The other side of the trade-off: The impact of risk on executive compensation, Journal of Political Economy 107-1, 65-105.

Aggarwal, Rajesh K., and Andrew A. Samwick, 2002, The other side of the trade-off: The impact of risk on executive compensation - A reply, Working Paper, Dartmouth College.

\footnotetext{
${ }^{19}$ Jin (2002) mentions that past stock returns and current period PPS could be related. For example, when firms suffer adverse shocks in previous years, they might decrease PPS to protect their executives from the adverse effect on their financial wealth. In our model specifications, we control for lagged one-year firm profitability. If we further include lagged one-year stock returns in the model (by including lagged dollar returns when the dependent variable is the dollar-to-dollar PPS and including lagged percentage returns when the dependent variable is the dollar-to-percentage PPS), we find that past stock returns have a significantly positive impact on incentives and that all our main results remain intact.
} 
Aggarwal, Rajesh K., and Andrew A. Samwick, 2003, Performance incentives within firms: The effect of managerial responsibility, Journal of Finance 58-4, 1613-1650.

Bae, Kee-Hong, Rene M. Stulz, and Hongping Tan, 2008, Do local analysts know more? A cross-country study of the performance of local analysts and foreign analysts, Journal of Financial Economics 88-3, 581-606.

Baker, George P., and Brian J. Hall, 2004, CEO incentives and firm size, Journal of Labor Economics 22-4, 767-798.

Baker, George P., and Bjorn Jorgensen, 2003, Volatility, noise and incentives, mimeo, Harvard University and Columbia University.

Baker, Malcolm, and Jeffrey Wurgler, 2006, Investor sentiment and the cross-section of stock returns, Journal of Finance 61-4, 1645-1680.

Becker, Bo, 2006, Wealth and executive compensation, Journal of Finance 61-1, 379-397.

Bitler, Marianne P., Tobias J. Moskowitz, and Annette Vissing-Jorgensen, 2005, Testing agency theory with entrepreneur effort and wealth, Journal of Finance 60-2, 539-576.

Bizjak, John M., James A. Brickley, and Jeffrey L. Coles, 1993, Stock-based incentive compensation and investment behavior, Journal of Accounting and Economics 16, 349-372.

Bushman, Robert M., Raffi J. Indjejikian, and Abbie Smith, 1996, CEO compensation: The role of individual performance evaluation, Journal of Accounting and Economics 21-2, 161-193.

Cleary, Sean, 1999, The relationship between firm investment and financial status, Journal of Finance 54-2, 673-692.

Coles, Jeffrey L., Naveen D. Daniel, and Lalitha Naveen, 2006, Managerial incentives and risk-taking, Journal of Financial Economics 79, 431-468.

Conyon, Martin J., and Kevin J. Murphy, 2000, The prince and the pauper? CEO pay in the United States and United Kingdom, Economic Journal 110-467, 640-671.

Core, John, and Wayne Guay, 1999, The use of equity grants to manage optimal equity incentive levels, Journal of Accounting and Economics 28-2, 151-184.

Core, John, and Wayne Guay, 2002, Estimating the value of employee stock option portfolios and their sensitivities to price and volatility, Journal of Accounting Research 40-3, 613-630.

Core, John, Wayne Guay, and Robert Verrecchia, 2003, Price versus non-price performance measures in optimal CEO compensation contracts, The Accounting Review 78-4, 957-981.

Core, John E., Robert W. Holthausen, and David F. Larcker, 1999, Corporate governance, chief executive officer compensation, and firm performance, Journal of Financial Economics 51-3, 371-406.

Cremers, Martijn, and Hongjun Yan, 2010, Uncertainty and Valuations, working paper, Yale University. 
DeMarzo Peter M., and Yuliy Sannikov, 2008, Learning in Dynamic Incentive Contracts, working paper, Stanford University and Princeton University.

Edmans, Alex, Xavier Gabaix, and Augustin Landier, 2009, A multiplicative model of optimal CEO incentives in market equilibrium, Review of Financial Studies 22-12, 4881-4917.

Gabaix, Xavier, and Augustin Landier, 2008, Why has CEO pay increased so much? Quarterly Journal of Economics 123-1, 49-100.

Garen, John E., 1994, Executive compensation and principal-agent theory, Journal of Political Economy $102-6,1175-1199$.

Garvey, Gerald, and Todd Milbourn, 2003, Incentive compensation when executives can hedge the market: Evidence of relative performance evaluation in the cross section, Journal of Finance 58-4, 1557-1582.

Graham, John R., Si Li, and Jiaping Qiu, 2011, Managerial Attributes and Executive Compensation, Review of Financial Studies, forthcoming.

Hall, Brian J., and Jeffrey B. Liebman, 1998, Are CEOs really paid like bureaucrats? Quarterly Journal of Economics 113-3, 653-691.

Himmelberg, Charles P., R. Glenn Hubbard, and Darius Palia, 1999, Understanding the determinants of managerial ownership and the link between ownership and performance, Journal of Financial Economics 53-3, 353-384.

Holmstrom, Bengt, and Paul Milgrom, 1987, Aggregation and linearity in the provision of intertemporal incentives, Econometrica 55-2, 303-328.

Jovanovic, Boyan, and Saul Lach, 1989, Entry, Exit, \& Diffusion with Learning by Doing, American Economic Review, 79-4, 690-699.

Jovanovic, Boyan, and Yaw Nyarko, 1996, Learning by Doing \& the Choice of Technology, Econometrica, 64-6, 1299-1310.

Jensen, Michael C., and Kevin J. Murphy, 1990, Performance pay and top management incentives, Journal of Political Economy 98-2, 225-264.

Jin, Li, 2002, CEO compensation, diversification, and incentives, Journal of Financial Economics 66-1, 29-63.

Johnson, Timothy, 2007, Optimal learning and new technology bubbles, Journal of Monetary Economics, $54,2486-2511$.

Kaplan, Steven N., and Luigi Zingales, 1997, Do investment-cash flow sensitivities provide useful measures of financing constraints?, Quarterly Journal of Economics 112, 169-215.

Korteweg, Arthur G., and Nicholas Polson, 2009, Corporate credit spreads under parameter uncertainty, working paper, Stanford University and University of Chicago. 
Lambert, Richard A., and David F. Larcker, 1987, An analysis of the use of accounting and market measures of performance in executive compensation contracts, Journal of Accounting Research 25, 85-125.

Lang, Mark H., and Russell J. Lundholm, 1996, Corporate disclosure policy and analyst behavior, The Accounting Review 71-4, 467-492.

Palia, Darius, 2001, The endogeneity of managerial compensation in firm valuation: A solution, Review of Financial Studies 14-3, 735-764.

Pastor, Lubos, Lucian A. Taylor, and Pietro Veronesi, 2009, Entrepreneurial learning, the IPO decision, and the post-IPO drop in firm profitability, Review of Financial Studies 22-8, 3005-3046.

Pastor, Lubos, and Pietro Veronesi, 2003, Stock valuation and learning about profitability, Journal of Finance 58-5, 1749-1790.

Prendergast, Canice, 2002, The tenuous trade-off between risk and incentives, Journal of Political Economy 110-5, 1071-1102.

Yermack, David, 1995, Do corporations award CEO stock options effectively?, Journal of Financial Economics 39-2, 237-269.

Zabojnik, Jan, 1996, Pay-performance sensitivity and production uncertainty, Economics Letters 53-3, 291-296.

\section{Appendix}

\section{Appendix A: Proofs}

Proof of Lemma 1. Note that given $\alpha, \beta$ and $L_{1}$, the manager's expected utility is:

$$
\begin{aligned}
& \mathbb{E}\left[-e^{-a\left(w_{1}-\frac{l}{2} L_{1}^{2}\right)}\right] \\
= & -\exp \left[-a\left(\alpha+\beta \theta_{0}\left(1+L_{1}\right)-\frac{l}{2} L_{1}^{2}-\frac{1}{2} a \beta^{2}\left(\gamma_{0}\left(1+L_{1}\right)^{2}+\sigma_{\epsilon}^{2}\right)\right)\right] .
\end{aligned}
$$

If we denote the above expected utility of the manager as $\bar{U}\left(L_{1}\right)$, then its first-order condition is

$$
\frac{d \bar{U}\left(L_{1}\right)}{d L_{1}}=\bar{U}\left(L_{1}\right)(-a)\left[\beta \theta_{0}-l L_{1}-a \gamma_{0} \beta^{2}\left(1+L_{1}\right)\right]
$$

and its second-order condition is

$$
\frac{d^{2} \bar{U}\left(L_{1}\right)}{d L_{1}^{2}}=(-a)^{2} \bar{U}\left(L_{1}\right)\left[\beta \theta_{0}-l L_{1}-a \gamma_{0} \beta^{2}\left(1+L_{1}\right)\right]^{2}+\bar{U}\left(L_{1}\right) a\left(l+a \gamma_{0} \beta^{2}\right)<0 .
$$

The optimal $L_{1}^{*}$ is determined by the first-order condition of the manager's optimization problem:

$$
L_{1}^{*}=\frac{\beta \theta_{0}-a \gamma_{0} \beta^{2}}{l+a \gamma_{0} \beta^{2}} .
$$


The fixed salary $\alpha$ is chosen to satisfy the manager's participation constraint:

$$
\alpha+\beta \theta_{0}\left(1+L_{1}^{*}\right)-\frac{l}{2} L_{1}^{* 2}-\frac{1}{2} a \beta^{2}\left(\gamma_{0}\left(1+L_{1}^{*}\right)^{2}+\sigma_{\epsilon}^{2}\right)=-\frac{1}{a} \log (-\widehat{U}) ;
$$

or, after substituting the expression of $L_{1}^{*}$ and $\widehat{U}=-1$, we have

$$
\alpha=-\beta \theta_{0} \frac{l+\theta_{0} \beta}{l+a \gamma_{0} \beta^{2}}+\frac{1}{2} \frac{\beta^{2}\left(\theta_{0}^{2}+a l \gamma_{0}\right)}{l+a \gamma_{0} \beta^{2}}+\frac{1}{2} a \sigma_{\epsilon}^{2} \beta^{2} .
$$

Proof of Proposition 1. We first prove that $\frac{d \beta^{*}}{d \gamma_{0}}>0$ holds when the manager is risk neutral (i.e., $a=0$ ). Then the statement in the proposition immediately follows in light of the continuity of the derivative $d \beta^{*} / d \gamma_{0}$ in $a$. We can view the maximization problem in terms of implemented effort $L_{1}^{*}$. If the optimal effort increases with uncertainty $\gamma_{0}$ :

$$
\frac{d L_{1}^{*}}{d \gamma_{0}}>0
$$

and if higher effort is linked to higher incentives, which requires

$$
\frac{d L_{1}^{*}}{d \beta}>0
$$

then we obtain our desired result $\frac{d \beta^{*}}{d \gamma_{0}}>0$. Below we proceed to show that both Eq. (10) and Eq. (11) hold.

When $a=0$, to implement $L_{1}^{*}$, the incentive share $\beta$ satisfies

$$
L_{1}^{*}=\frac{\beta \theta_{0}}{l} .
$$

Immediately we know that $\frac{d L_{1}^{*}}{d \beta}=\frac{\theta_{0}}{l}>0$, which is just Eq. (11). Now we use supermodularity property to prove $\frac{d L_{1}^{*}}{d \gamma_{0}}>0$. Recall that

Taking expectation, we have

$$
V_{2}\left(\theta_{1}\right)=\theta_{1}+\frac{\left(\theta_{1}-1\right)^{2}}{2 k}+\frac{\theta_{1}^{2}}{2 k}
$$

$$
\begin{aligned}
\mathbb{E}\left[V_{2}\left(\theta_{1}\right)\right] & =\theta_{0}+\frac{\left(1-\theta_{0}\right)^{2}}{2 k}+\frac{\theta_{0}^{2}}{2 l}+\frac{k+l}{2 k l}\left(\frac{\gamma_{1}\left(1+L_{1}^{*}\right)}{\sigma_{\epsilon}^{2}}\right)^{2} \mathbb{E}\left(\left(\theta-\theta_{0}\right)\left(1+L_{1}^{*}\right)+\epsilon_{1}\right)^{2} \\
& =\theta_{0}+\frac{\left(1-\theta_{0}\right)^{2}}{2 k}+\frac{\theta_{0}^{2}}{2 l}+\frac{k+l}{2 k l} \frac{\gamma_{0}^{2}\left(1+L_{1}^{*}\right)^{2}}{\sigma_{\epsilon}^{2}+\gamma_{0}\left(1+L_{1}^{*}\right)^{2}} .
\end{aligned}
$$

Therefore, we can rewrite the principal's objective as (to reduce notation, we use $L$ to denote $L_{1}^{*}$ ),

$$
\begin{aligned}
V\left(L, \gamma_{0}\right)= & \mathbb{E}_{0}\left(y_{1}-w_{1}+V_{2}\left(\theta_{1}^{*}\right)\right) \\
= & \theta_{0}(L+1)-\frac{1}{2} L^{2} l-\frac{1}{2} a\left(\gamma_{0}\left(1+L_{1}^{*}\right)^{2}+\sigma_{\epsilon}^{2}\right) \beta^{2} \\
& +\frac{k+l}{2 k l} \frac{\gamma_{0}^{2}(1+L)^{2}}{\sigma_{\epsilon}^{2}+\gamma_{0}(1+L)^{2}}+\theta_{0}+\frac{\left(1-\theta_{0}\right)^{2}}{2 k}+\frac{\theta_{0}^{2}}{2 l}
\end{aligned}
$$


Hence, for $a=0$, and ignoring the constant terms, we have

$$
V\left(L, \gamma_{0}\right)=\theta_{0}(L+1)-\frac{1}{2} L^{2} l+\frac{k+l}{2 k l} \frac{\gamma_{0}^{2}(1+L)^{2}}{\sigma_{\epsilon}^{2}+\gamma_{0}(1+L)^{2}},
$$

where the first term is the first period project value, the second term is the effort cost, and the last term is the second period value. It suffices to show that

$$
\frac{\partial^{2} V\left(L, \gamma_{0}\right)}{\partial L \partial \gamma_{0}}>0
$$

The first two terms are irrelevant. For the last term, notice that (treating $(1+L)^{2}$ as a single variable)

$$
\begin{aligned}
\frac{\frac{k+l}{2 k l} \partial \frac{\gamma_{0}^{2}(1+L)^{2}}{\sigma_{\epsilon}^{2}+\gamma_{0}(1+L)^{2}}}{\partial(L+1)^{2}} & =\frac{k+l}{2 k l}\left[\frac{\gamma_{0}^{2}}{\sigma_{\epsilon}^{2}+\gamma_{0}(L+1)^{2}}-\frac{\gamma_{0}^{3}(L+1)^{2}}{\left(\sigma_{\epsilon}^{2}+\gamma_{0}(L+1)^{2}\right)^{2}}\right] \\
& =\frac{k+l}{2 k l} \frac{\sigma_{\epsilon}^{2}}{\left(\frac{\sigma_{\epsilon}^{2}}{\gamma_{0}}+(L+1)^{2}\right)^{2}},
\end{aligned}
$$

which is increasing in $\gamma_{0}$. Thus, $\frac{\partial^{2} V\left(L, \gamma_{0}\right)}{\partial L \partial \gamma_{0}}>0$. Therefore, we have proven $\frac{d L_{1}^{*}}{d \gamma_{0}}>0$, and hence $\frac{d \beta^{*}}{d \gamma_{0}}>0$ for $a=0$. Invoking conitnuity argument, we conclude that our result holds when $a$ is sufficiently small.

\section{Appendix B: Definition of Variables}

\section{Firm Level Variables}

Firm age: Based on Pastor and Veronesi (2003), we consider each firm as "born" in the year of its first appearance in the CRSP database. Specifically, we look for the first occurrence of a valid stock price on CRSP, as well as the first occurrence of a valid market value in the CRSP / COMPUSTAT database, and take the earlier of the two. The firm's plain age is assigned the value of one in the year in which the firm is born and increases by one in each subsequent year. We use natural log of firm's plain age as the proxy for uncertainty.

Earnings response coefficient (ERC): This variable is the ERC1 as defined in Pastor, et al. (2009) and is equal to the average of the firm's previous 12 stock price reactions to quarterly earnings surprises. Specifically, we first obtain RC, which is the abnormal return due to a quarterly earnings announcement divided by the unexpected quarterly earnings. The abnormal return is measured as the cumulative return of stock i in excess of stock i's industry's return starting one trading day before the firm's earnings announcement and ending one trading day after the same announcement. Quarterly earnings announcement dates are from IBES. The industry returns are the daily returns of 49 value-weighted industry portfolios from Ken French's website. The unexpected quarterly earnings are equal to the difference between the actual quarterly earnings per share (obtained from the IBES unadjusted actuals file) and the mean of all analyst forecasts of EPS using IBES's last preannouncement set of forecasts for the given fiscal quater, deflated by book equity per share of the company. We winsorize $\mathrm{RC}$ at $5 \%$ and $95 \%$ and average the winsorized quarterly RCs over the rolling three year window to obtain ERC1. Pastor et al. (2009) contain more detailed information on constructing the ERC variables. 
Market to book: (Market value of equity plus the book value of debt $) /$ total assets $=(\mathrm{CSHO} \times \mathrm{PRCC} F$ $+\mathrm{AT}-\mathrm{CEQ}) / \mathrm{AT}=($ data25 $\times$ data199+data6-data60 $) /$ data6 .

Tangibility: Net property, plant, and equipment/total assets $=\mathrm{PPENT} / \mathrm{AT}=$ data $8 /$ data6 .

Analyst forecast error: For each individual company in each fiscal year, we first obtain the absolute value of the forecast error (equal to the difference between the forecast and the actual EPS values) made by each analyst, and then we use the median value of these absolute forecast errors scaled by the absolute value of the actual EPS. Using the mean value of the absolute forecast errors or scaling by stock price per share gives similar results. The analyst forecast error variable is constructed from the $\mathrm{I} / \mathrm{B} / \mathrm{E} / \mathrm{S}$ details database.

Stock return volatility: First obtain the standard deviation of daily log returns over the past five years, and then annualize the standard deviation by multiplying by the square root of 254 . This is the percentage return volatility.

Rank of dollar return volatility: Dollar return volatility is equal to stock percentage return volatility multiplied by the beginning-of-year firm market value. This variable is measured in \$millions. Consistent with Aggarwal and Samwick (1999) and Jin (2002), we employ the percentage ranks of dollar return variance in our tests and these percentage ranks range from 0 (lowest risk) to 100 (highest risk).

Investment volatility: This variable is the standard deviation of firm investment over the past 20 quarters, where firm investment is $I_{t} / K_{t-1}$, that is, it is equal to capital expenditure in each quarter scaled by previous quarter-end net property, plant, and equipment (PPENTQ).

Firm size: Natural $\log$ of total assets $=\log (\mathrm{AT})=\log ($ data6). Assets are measured in \$millions.

Profitability: Operating income before depreciation and amortization/total assets $=$ OIBDP/AT $=$ data13/data6.

Capital expenditure: Capital expenditures/total assets $=\mathrm{CAPX} / \mathrm{AT}=$ data128/data6.

Advertisement: Advertising expense/total assets $=\mathrm{XAD} / \mathrm{AT}=$ data45/data6. This variable is set to zero if it is missing and an advertisement missing indicator is thus included in the regressions to deal with the missing advertisement issue.

Advertisement missing indicator: A dummy variable equal to one if the advertisement variable is missing.

Leverage: $($ Long term debt + debt in current liabilities $) /$ total assets $=($ DLTT + DLC $) / A T=($ data9 + data34 $) /$ data6.

Dividend-paying indicator: A dummy variable equal to one if dividends on common stock (data21 or DVC) are strictly positive, and zero otherwise.

CEO chair indicator: A dummy variable equal to one if the CEO of the company is also the board chairman, and zero otherwise.

Fraction of inside directors: Number of inside board directors divided by board size, where an inside director is defined as a director who is current or former firm managers or their family members. 


\section{Manager Level Variables}

PPS1: Dollar-to-dollar measure of pay-performance sensitivity. This variable measures the dollar change in stock and option holdings for a one dollar change in firm value. To estimate PPS1, first calculate a variable named totaldelta, which is obtained from multiplying the Black-Scholes hedge ratio by the shares in options owned by the executive, and then adding the shares in stock owned by the executive. PPS1 in year $t$ is equal to an executive's totaldelta over fiscal year $t$ divided by total number of shares outstanding (Compustat data item CSHO) of the company at the beginning of year t. The construction of totaldelta involves lots of details (e.g., how to construct Black-Scholes hedge ratio, how to deal with previously granted options, what to assume for expected life on the options, etc.), and we follow Appendix B in Edmans, et al. (2009) in estimating the totaldelta variable. In the regressions, PPS1 is in percentages.

PPS2: Dollar-to-percentage measure of pay-performance sensitivity. This variable measures the dollar change in stock and option holdings for a one percent change in firm value. PPS2 in year $t$ is equal to PPS1 in year $t \times$ share price at the beginning of fiscal year $t \times$ total number of shares outstanding at the beginning of $\mathrm{t} / 100$, where share price is Compustat data item PRCC_F and total number of shares outstanding is Compustat data item CSHO. In the regressions, PPS2 is in \$thousands.

PPS2: Dollar-to-percentage measure of pay-performance sensitivity. It measures the dollar change in stock and option holdings for a one percent change in firm value. This measure is equal to PPS $1 \times$ share price $\times$ total number of shares outstanding/100. In the regressions, PPS2 is in \$thousands.

WPS: This is the scaled wealth-performance sensitivity proposed in Edmans et al. (2009) and is available from Alex Edmans' website. Specifically, this sensitivity measure equals the dollar change in executive wealth for a 100 percentage point change in firm value, divided by annual flow compensation (TDC1). This incentive measure is a variant of the percentage-to-percentage incentives used in Murphy (1985), Gibbons and Murphy (1992), and Rosen (1992), and replaces flow compensation in the numerator of the measure in Murphy (1985) with the change in the executives' wealth. By considering the change in wealth, the scaled wealth-performance sensitivity captures the important incentives from changes in the value of previously granted stock and options. See Edmans et al. (2009) for details.

$\log ($ tenure): Natural log of the number of years the manager has been with the company, which equals the difference between the year of the observation and the year when the individual joined the company.

CEO indicator: A dummy variable that equals one if the manager is the CEO in a particular year and zero if the manager is a non-CEO top executive. This dummy variable is time variant for a given individual because a specific manager could be a CEO in some years and a non-CEO in other years.

Female indicator: A dummy variable that equals one if the manager is a female and zero otherwise. 
Table 1

Summary Statistics

The table provides summary statistics of the variables. The detailed definitions of the variables are in Appendix B.

\begin{tabular}{|c|c|c|c|c|c|c|}
\hline Variables & $\mathbf{N}$ & Mean & Stdev & Median & Min & Max \\
\hline \multicolumn{7}{|c|}{ Dependent variable: Pay-performance sensitivity } \\
\hline PPS1 & 179,930 & $1.13 \%$ & $3.15 \%$ & $0.22 \%$ & $0 \%$ & $22.66 \%$ \\
\hline PPS2 (\$thousands) & 179,930 & 168.61 & 476.91 & 27.97 & 0 & $3,519.93$ \\
\hline WPS & 169,841 & 36.34 & 119.97 & 6.77 & 0 & 939.61 \\
\hline Investment volatility & 151,954 & 6.05 & 14.00 & 3.00 & 0.19 & 336.20 \\
\hline \multicolumn{7}{|l|}{ Profitability uncertainty variables } \\
\hline Firm age & 143,291 & 25.56 & 20.02 & 20 & 1 & 84 \\
\hline Earnings response coefficient (ERC) & 117,263 & 4.44 & 10.40 & 2.88 & -57.01 & 75.09 \\
\hline Market to book & 141,405 & 2.08 & 2.03 & 1.51 & 0.51 & 43.19 \\
\hline Tangibility & 139,799 & 0.29 & 0.24 & 0.23 & 0 & 0.94 \\
\hline Analyst forecast error & 131,689 & 0.16 & 0.55 & 0.03 & 0 & 6 \\
\hline \multicolumn{7}{|l|}{ Risk variable } \\
\hline Stock return volatility & 141,623 & 0.44 & 0.20 & 0.39 & 0.18 & 1.14 \\
\hline Dollar return volatility (\$millions) & 108,557 & 1497.20 & 2639.38 & 477.79 & 27.98 & 14382.63 \\
\hline \multicolumn{7}{|l|}{ Control variables } \\
\hline Total assets (\$millions) & 143,182 & 6,589 & 14,022 & 1,343 & 0.07 & 72,282 \\
\hline Profitability & 140,222 & 0.13 & 0.13 & 0.13 & -5.09 & 0.45 \\
\hline Capital expenditure & 134,919 & 0.06 & 0.06 & 0.05 & 0 & 0.48 \\
\hline Advertisement & 143,195 & 0.01 & 0.03 & 0 & 0 & 0.19 \\
\hline Advertisement missing indicator & 143,195 & 0.69 & 0.46 & 1 & 0 & 1 \\
\hline Leverage & 142,528 & 0.23 & 0.20 & 0.21 & 0 & 3.09 \\
\hline Dividend paying indicator & 143,195 & 0.57 & 0.50 & 1 & 0 & 1 \\
\hline CEO chair indicator & 163,936 & 0.65 & 0.48 & 1 & 0 & 1 \\
\hline Fraction of inside directors & 163,936 & 0.27 & 0.14 & 0.25 & 0 & 0.9 \\
\hline Tenure & 173,383 & 9.23 & 5.85 & 8.86 & 0 & 40 \\
\hline CEO indicator & 179,930 & 0.15 & 0.35 & 0 & 0 & 1 \\
\hline Female indicator & 179,930 & 0.05 & 0.22 & 0 & 0 & 1 \\
\hline
\end{tabular}


Table 2

\section{Correlations between Variables}

The table includes pairwise correlations of the main variables used in the regressions. The detailed definitions of the variables are in Appendix B.

\begin{tabular}{|c|c|c|c|c|c|c|c|c|c|c|c|}
\hline & \multicolumn{3}{|c|}{ Incentives } & \multirow[b]{2}{*}{ invvol } & \multicolumn{5}{|c|}{ Profitability Uncertainty } & \multicolumn{2}{|c|}{ Risk } \\
\hline & PPS1 & PPS2 & WPS & & age & ERC & $\mathrm{M} / \mathrm{B}$ & tang & forerr & vol & dolvol \\
\hline PPS2 & 0.55 & 1 & & & & & & & & & \\
\hline $\begin{array}{l}\text { Wealth-performance } \\
\text { sensitivity (WPS) }\end{array}$ & 0.21 & 0.25 & 1 & & & & & & & & \\
\hline $\begin{array}{c}\text { Investment volatility } \\
\text { (invvol) }\end{array}$ & 0.08 & 0.02 & 0.05 & 1 & & & & & & & \\
\hline Log(firm age) (age) & -0.16 & 0.003 & -0.10 & -0.24 & 1 & & & & & & \\
\hline $\begin{array}{l}\text { Earnings response } \\
\text { coefficient (ERC) }\end{array}$ & 0.04 & 0.05 & 0.07 & 0.007 & -0.06 & 1 & & & & & \\
\hline Market to book (M/B) & 0.08 & 0.20 & 0.19 & 0.16 & -0.23 & 0.07 & 1 & & & & \\
\hline Tangibility (tang) & -0.05 & -0.08 & -0.03 & -0.15 & 0.18 & -0.06 & -0.12 & 1 & & & \\
\hline $\begin{array}{l}\text { Analyst forecast error } \\
\text { (forerr) }\end{array}$ & 0.02 & -0.04 & -0.01 & 0.05 & -0.04 & -0.05 & -0.04 & 0.01 & 1 & & \\
\hline $\begin{array}{l}\text { Stock return volatility } \\
\text { (vol) }\end{array}$ & 0.10 & -0.03 & 0.03 & 0.28 & -0.44 & -0.04 & 0.23 & -0.22 & 0.13 & 1 & \\
\hline $\begin{array}{l}\text { Rank of dollar return } \\
\text { volatility (dolvol) }\end{array}$ & -0.14 & 0.29 & 0.09 & -0.06 & 0.23 & 0.01 & 0.16 & -0.06 & -0.12 & -0.12 & 1 \\
\hline Firm size (size) & -0.20 & 0.19 & -0.03 & -0.20 & 0.44 & -0.01 & -0.24 & 0.03 & -0.10 & -0.48 & 0.73 \\
\hline
\end{tabular}


Table 3

\section{Effects of Profitability Uncertainty and Risk on Incentives (PPS1)}

The table presents the OLS regression results on the effects of profitability uncertainty and risk on incentives. The dependent variable is the dollar-to-dollar measure (PPS1) of pay-performance sensitivity. All the explanatory variables are lagged by one year. The sample includes all the companies in ExecuComp and covers the period from 1992 to 2008. The detailed definitions of all the variables are in Appendix B. Heteroskedasticity robust t-statistics adjusting for clustering within companies are in parentheses. Significance at the $10 \%, 5 \%$, and $1 \%$ levels is indicated by *, **, and ***.

\begin{tabular}{|c|c|c|c|c|c|c|c|}
\hline Dependent variable $=$ PPS1 & (1) & (2) & (3) & (4) & (5) & (6) & (7) \\
\hline \multicolumn{8}{|c|}{ Profitability uncertainty variables } \\
\hline Log(firm age) (-) & -- & $\begin{array}{c}-0.22 * * * \\
(-6.66)\end{array}$ & -- & -- & -- & -- & $\begin{array}{c}-0.24^{* * *} \\
(-6.98)\end{array}$ \\
\hline ERC $(+)$ & -- & -- & $\begin{array}{l}0.0075^{* * * *} \\
\quad(4.47)\end{array}$ & -- & -- & -- & $\begin{array}{c}0.007^{* * * *} \\
(4.07)\end{array}$ \\
\hline Market to book (+) & -- & -- & -- & $\begin{array}{c}0.03^{* * *} \\
(2.64)\end{array}$ & -- & -- & $\begin{array}{c}0.02 \\
(1.28)\end{array}$ \\
\hline Tangibility (-) & -- & -- & -- & -- & $\begin{array}{c}-0.53 * * * \\
(-3.05)\end{array}$ & -- & $\begin{array}{l}-0.30^{*} \\
(-1.71)\end{array}$ \\
\hline Analyst forecast error (+) & -- & -- & -- & -- & -- & $\begin{array}{c}0.03 \\
(1.37)\end{array}$ & $\begin{array}{l}0.04^{*} \\
(1.88)\end{array}$ \\
\hline \multicolumn{8}{|l|}{ Risk variable } \\
\hline Stock return volatility & $\begin{array}{l}0.39 * * \\
(2.25)\end{array}$ & $\begin{array}{c}0.15 \\
(0.87)\end{array}$ & $\begin{array}{c}0.57 * * * \\
(2.99)\end{array}$ & $\begin{array}{l}0.34^{*} \\
(1.94)\end{array}$ & $\begin{array}{l}0.35^{* *} \\
(1.97)\end{array}$ & $\begin{array}{c}0.51 * * * \\
(2.94)\end{array}$ & $\begin{array}{c}0.21 \\
(1.13)\end{array}$ \\
\hline \multicolumn{8}{|l|}{ Control variables } \\
\hline Firm size & $\begin{array}{c}-0.31 * * * \\
(-16.28)\end{array}$ & $\begin{array}{c}-0.28 * * * \\
(-13.81)\end{array}$ & $\begin{array}{c}-0.28 * * * \\
(-14.73)\end{array}$ & $\begin{array}{c}-0.31 * * * \\
(-16.06)\end{array}$ & $\begin{array}{c}-0.31 * * * \\
(-16.07)\end{array}$ & $\begin{array}{c}-0.29 * * * \\
(-15.93)\end{array}$ & $\begin{array}{r}-0.25 * * * \\
(-12.43)\end{array}$ \\
\hline Profitability & $\begin{array}{c}0.31 \\
(1.61)\end{array}$ & $\begin{array}{c}0.20 \\
(1.06)\end{array}$ & $\begin{array}{c}0.34 \\
(1.63)\end{array}$ & $\begin{array}{c}0.21 \\
(1.05)\end{array}$ & $\begin{array}{l}0.34^{*} \\
(1.75)\end{array}$ & $\begin{array}{c}0.32 \\
(1.64)\end{array}$ & $\begin{array}{c}0.18 \\
(0.85)\end{array}$ \\
\hline Capital expenditure & $\begin{array}{c}1.19 * * * \\
(2.96)\end{array}$ & $\begin{array}{l}0.99 * * \\
(2.45)\end{array}$ & $\begin{array}{c}1.21^{* * *} \\
(2.94)\end{array}$ & $\begin{array}{c}1.13^{* * *} \\
(2.78)\end{array}$ & $\begin{array}{c}1.96 * * * \\
(4.59)\end{array}$ & $\begin{array}{c}1.43^{* * *} \\
(3.53)\end{array}$ & $\begin{array}{c}1.46^{* * * *} \\
(3.44)\end{array}$ \\
\hline Advertisement & $\begin{array}{l}1.06 \\
(0.92)\end{array}$ & $\begin{array}{c}1.19 \\
(1.02)\end{array}$ & $\begin{array}{c}1.20 \\
(1.01)\end{array}$ & $\begin{array}{c}1.02 \\
(0.88)\end{array}$ & $\begin{array}{c}0.95 \\
(0.82)\end{array}$ & $\begin{array}{c}1.30 \\
(1.13)\end{array}$ & $\begin{array}{c}1.22 \\
(1.05)\end{array}$ \\
\hline $\begin{array}{l}\text { Advertisement missing } \\
\text { dummy }\end{array}$ & $\begin{array}{l}-0.03 \\
(-0.43)\end{array}$ & $\begin{array}{l}-0.02 \\
(-0.35)\end{array}$ & $\begin{array}{c}0.03 \\
(0.49)\end{array}$ & $\begin{array}{l}-0.02 \\
(-0.40)\end{array}$ & $\begin{array}{l}-0.02 \\
(-0.35)\end{array}$ & $\begin{array}{l}0.007 \\
(0.13)\end{array}$ & $\begin{array}{c}0.03 \\
(0.55)\end{array}$ \\
\hline Leverage & $\begin{array}{l}-0.13 \\
(-0.90)\end{array}$ & $\begin{array}{c}-0.13 \\
(-0.89)\end{array}$ & $\begin{array}{c}-0.20 \\
(-1.46)\end{array}$ & $\begin{array}{l}-0.12 \\
(-0.85)\end{array}$ & $\begin{array}{l}-0.06 \\
(-0.39)\end{array}$ & $\begin{array}{l}-0.25^{*} \\
(-1.86)\end{array}$ & $\begin{array}{l}-0.14 \\
(-1.00)\end{array}$ \\
\hline Dividend paying indicator & $\begin{array}{c}-0.28 * * * \\
(-4.76)\end{array}$ & $\begin{array}{c}-0.20 * * * \\
(-3.29)\end{array}$ & $\begin{array}{c}-0.27 * * * \\
(-4.37)\end{array}$ & $\begin{array}{c}-0.28 * * * \\
(-4.74)\end{array}$ & $\begin{array}{c}-0.27 * * * \\
(-4.51)\end{array}$ & $\begin{array}{c}-0.27 * * * \\
(-4.70)\end{array}$ & $\begin{array}{c}-0.17 * * * \\
(-2.70)\end{array}$ \\
\hline CEO chair indicator & $\begin{array}{c}0.30 * * * \\
(7.07)\end{array}$ & $\begin{array}{c}0.30 * * * \\
(7.12)\end{array}$ & $\begin{array}{c}0.26^{* * *} \\
(6.22)\end{array}$ & $\begin{array}{c}0.29 * * * \\
(6.95)\end{array}$ & $\begin{array}{c}0.30 * * * \\
(7.02)\end{array}$ & $\begin{array}{c}0.27 * * * \\
(6.56)\end{array}$ & $\begin{array}{c}0.26^{* * * *} \\
(6.27)\end{array}$ \\
\hline Fraction of inside directors & $\begin{array}{c}2.65^{* * * *} \\
(12.55)\end{array}$ & $\begin{array}{c}2.60 * * * \\
(12.43)\end{array}$ & $\begin{array}{c}2.41^{* * *} \\
(11.47)\end{array}$ & $\begin{array}{c}2.62 * * * \\
(12.47)\end{array}$ & $\begin{array}{c}2.61^{* * *} \\
(12.25)\end{array}$ & $\begin{array}{c}2.50 * * * \\
(12.02)\end{array}$ & $\begin{array}{l}2.28^{* * *} \\
(10.89)\end{array}$ \\
\hline Log(tenure) & $\begin{array}{c}0.59 * * * \\
(14.74)\end{array}$ & $\begin{array}{c}0.60 * * * \\
(15.01)\end{array}$ & $\begin{array}{c}0.58^{* * *} \\
(14.66)\end{array}$ & $\begin{array}{c}0.59 * * * \\
(14.82)\end{array}$ & $\begin{array}{c}0.60^{* * *} \\
(14.76)\end{array}$ & $\begin{array}{c}0.58^{* * *} \\
(15.11)\end{array}$ & $\begin{array}{c}0.60^{* * * *} \\
(14.91)\end{array}$ \\
\hline CEO indicator & $\begin{array}{c}2.80 * * * \\
(30.67)\end{array}$ & $\begin{array}{c}2.79 * * * \\
(30.66)\end{array}$ & $\begin{array}{c}2.71 * * * \\
(28.90)\end{array}$ & $\begin{array}{c}2.79 * * * \\
(30.69)\end{array}$ & $\begin{array}{c}2.80 * * * \\
(30.51)\end{array}$ & $\begin{array}{c}2.76^{* * *} \\
(30.57)\end{array}$ & $\begin{array}{c}2.71^{* * * *} \\
(28.62)\end{array}$ \\
\hline Female indicator & $\begin{array}{c}-0.20 * * \\
(-2.42)\end{array}$ & $\begin{array}{c}-0.20 * * \\
(-2.51)\end{array}$ & $\begin{array}{c}-0.23 * * * \\
(-3.13)\end{array}$ & $\begin{array}{c}-0.20 * * \\
(-2.50)\end{array}$ & $\begin{array}{c}-0.20 * * \\
(-2.46)\end{array}$ & $\begin{array}{c}-0.21^{* * * *} \\
(-2.89)\end{array}$ & $\begin{array}{c}-0.24 * * * \\
(-3.25)\end{array}$ \\
\hline Year dummies & Yes & Yes & Yes & Yes & Yes & Yes & Yes \\
\hline Two digit SIC dummies & Yes & Yes & Yes & Yes & Yes & Yes & Yes \\
\hline Adjusted $\mathrm{R}^{2}$ & 0.21 & 0.21 & 0.21 & 0.21 & 0.21 & 0.21 & 0.22 \\
\hline Number of observations & 119,281 & 119,281 & 102,537 & 119,079 & 118,149 & 113,496 & 100,760 \\
\hline
\end{tabular}


Table 4

\section{Effects of Profitability Uncertainty and Risk on Incentives (PPS2)}

The table presents the OLS regression results on the effects of profitability uncertainty and risk on incentives. The dependent variable is the dollar-to-percentage measure (PPS2) of pay-performance sensitivity. All the explanatory variables are lagged by one year. The sample includes all the companies in ExecuComp and covers the period from 1992 to 2008. The detailed definitions of all the variables are in the Appendix. Heteroskedasticity robust t-statistics adjusting for clustering within companies are in parentheses. Significance at the $10 \%, 5 \%$, and $1 \%$ levels is indicated by $*, * *$, and $* * *$.

\begin{tabular}{|c|c|c|c|c|c|c|c|}
\hline $\begin{array}{c}\text { Dependent variable }= \\
\text { PPS2 }\end{array}$ & (1) & (2) & (3) & (4) & (5) & (6) & (7) \\
\hline \multicolumn{8}{|c|}{ Profitability uncertainty variables } \\
\hline Log(firm age) (-) & -- & $\begin{array}{c}-44.02 * * * \\
(-7.35)\end{array}$ & -- & -- & -- & -- & $\begin{array}{c}-37.28 * * * \\
(-6.00)\end{array}$ \\
\hline $\operatorname{ERC}(+)$ & -- & -- & $\begin{array}{c}1.57 * * * \\
(4.90)\end{array}$ & -- & -- & -- & $\begin{array}{c}1.06^{* * *} \\
(3.65)\end{array}$ \\
\hline Market to book (+) & -- & -- & -- & $\begin{array}{c}58.47 * * * \\
(15.47)\end{array}$ & -- & -- & $\begin{array}{c}63.43^{* * *} \\
(15.35)\end{array}$ \\
\hline Tangibility (-) & -- & -- & -- & -- & $\begin{array}{c}-266.10^{* * * *} \\
(-8.45)\end{array}$ & -- & $\begin{array}{c}-120.99 * * * \\
(-4.05)\end{array}$ \\
\hline Analyst forecast error $(+)$ & -- & -- & -- & -- & -- & $\begin{array}{l}-6.28 \\
(-1.55)\end{array}$ & $\begin{array}{c}2.91 \\
(0.95)\end{array}$ \\
\hline \multicolumn{8}{|l|}{ Risk variable } \\
\hline Stock return volatility & $\begin{array}{c}131.00^{* * *} \\
(4.14)\end{array}$ & $\begin{array}{c}82.07 * * * \\
(2.69)\end{array}$ & $\begin{array}{l}183.09^{* * *} \\
(5.11)\end{array}$ & $\begin{array}{l}20.47 \\
(0.73)\end{array}$ & $\begin{array}{l}110.49 * * * \\
(3.53)\end{array}$ & $\begin{array}{c}166.52^{* * *} \\
(5.05)\end{array}$ & $\begin{array}{l}-17.15 \\
(-0.54)\end{array}$ \\
\hline \multicolumn{8}{|l|}{ Control variables } \\
\hline Firm size & $\begin{array}{c}91.80^{* * *} \\
(18.29)\end{array}$ & $\begin{array}{c}98.38 * * * \\
(18.76)\end{array}$ & $\begin{array}{c}98.27^{* * *} \\
(18.03)\end{array}$ & $\begin{array}{c}95.44 * * * \\
(20.93)\end{array}$ & $\begin{array}{c}91.82^{* * *} \\
(18.45)\end{array}$ & $\begin{array}{c}95.60^{* * *} \\
(18.40)\end{array}$ & $\begin{array}{c}102.77 * * * \\
(20.48)\end{array}$ \\
\hline Profitability & $\begin{array}{c}267.08^{* * * *} \\
(4.88)\end{array}$ & $\begin{array}{c}244.72^{* * *} \\
(54.58)\end{array}$ & $\begin{array}{c}383.79 * * * \\
(7.60)\end{array}$ & $\begin{array}{c}97.49 * * * \\
(2.67)\end{array}$ & $\begin{array}{l}277.81^{* * *} \\
(5.13)\end{array}$ & $\begin{array}{l}304.07 * * * \\
(5.74)\end{array}$ & $\begin{array}{l}45.21 \\
(1.30)\end{array}$ \\
\hline Capital expenditure & $\begin{array}{c}330.39 * * * \\
(4.40)\end{array}$ & $\begin{array}{c}288.72^{* * *} \\
(3.94)\end{array}$ & $\begin{array}{l}302.56^{* * *} \\
(3.78)\end{array}$ & $\begin{array}{l}158.46^{* *} \\
(2.40)\end{array}$ & $\begin{array}{c}717.60 * * * \\
(9.14)\end{array}$ & $\begin{array}{c}302.27 * * * \\
(4.02)\end{array}$ & $\begin{array}{c}348.27 * * * \\
(4.67)\end{array}$ \\
\hline Advertisement & $\begin{array}{l}523.85^{* * *} \\
(2.65)\end{array}$ & $\begin{array}{c}548.66^{* * *} \\
(2.80)\end{array}$ & $\begin{array}{l}498.74^{* *} \\
(2.35)\end{array}$ & $\begin{array}{l}409.04^{* *} \\
(2.25)\end{array}$ & $\begin{array}{c}459.35 * * \\
(2.39)\end{array}$ & $\begin{array}{l}539.23^{* * * *} \\
(2.61)\end{array}$ & $\begin{array}{c}392.12^{* *} \\
(2.05)\end{array}$ \\
\hline $\begin{array}{l}\text { Advertisement missing } \\
\text { dummy }\end{array}$ & $\begin{array}{c}-0.63 \\
(-0.06)\end{array}$ & $\begin{array}{c}0.28 \\
(0.03)\end{array}$ & $\begin{array}{c}3.42 \\
(0.30)\end{array}$ & $\begin{array}{c}5.27 \\
(0.53)\end{array}$ & $\begin{array}{c}0.49 \\
(0.05)\end{array}$ & $\begin{array}{c}2.85 \\
(0.25)\end{array}$ & $\begin{array}{c}6.12 \\
(0.60)\end{array}$ \\
\hline Leverage & $\begin{array}{c}-193.27 * * * \\
(-6.46)\end{array}$ & $\begin{array}{c}-193.08 * * * \\
(-6.56)\end{array}$ & $\begin{array}{c}-204.84^{* * *} \\
(-6.31)\end{array}$ & $\begin{array}{c}-131.70 * * * \\
(-5.41)\end{array}$ & $\begin{array}{c}-167.08 * * * \\
(-5.89)\end{array}$ & $\begin{array}{c}-218.25^{* * *} \\
(-6.97)\end{array}$ & $\begin{array}{c}-122.20 * * * \\
(-4.50)\end{array}$ \\
\hline Dividend paying indicator & $\begin{array}{c}-54.65 * * * \\
(-5.04)\end{array}$ & $\begin{array}{c}-37.83 * * * \\
(-3.51)\end{array}$ & $\begin{array}{c}-56.24 * * * \\
(-4.80)\end{array}$ & $\begin{array}{c}-52.57 * * * \\
(-5.34)\end{array}$ & $\begin{array}{c}-47.66 * * * \\
(-4.48)\end{array}$ & $\begin{array}{c}-57.90 * * * \\
(-5.24)\end{array}$ & $\begin{array}{c}-33.87 * * * \\
(-3.22)\end{array}$ \\
\hline CEO chair indicator & $\begin{array}{c}22.30^{* * *} \\
(3.07)\end{array}$ & $\begin{array}{c}22.36 * * * \\
(3.12)\end{array}$ & $\begin{array}{c}22.35^{* * *} \\
(2.99)\end{array}$ & $\begin{array}{c}20.55^{* * *} \\
(3.12)\end{array}$ & $\begin{array}{c}20.92 * * * \\
(2.91)\end{array}$ & $\begin{array}{c}21.95^{* * *} \\
(2.97)\end{array}$ & $\begin{array}{c}18.90 * * * \\
(2.81)\end{array}$ \\
\hline $\begin{array}{l}\text { Fraction of inside } \\
\text { directors }\end{array}$ & $\begin{array}{c}344.27 * * * \\
(10.05)\end{array}$ & $\begin{array}{c}334.78^{* * *} \\
(9.90)\end{array}$ & $\begin{array}{c}346.12 * * * \\
(9.50)\end{array}$ & $\begin{array}{c}336.26^{* * *} \\
(10.47)\end{array}$ & $\begin{array}{c}328.53^{* * *} \\
(9.76)\end{array}$ & $\begin{array}{c}341.59 * * * \\
(9.63)\end{array}$ & $\begin{array}{c}307.54 * * * \\
(9.13)\end{array}$ \\
\hline Log(tenure) & $\begin{array}{c}82.08^{* * *} \\
(13.78)\end{array}$ & $\begin{array}{c}84.66 * * * \\
(14.20)\end{array}$ & $\begin{array}{c}86.40 * * * \\
(13.44)\end{array}$ & $\begin{array}{c}84.48^{* * *} \\
(14.54)\end{array}$ & $\begin{array}{c}83.44 * * * \\
(13.97)\end{array}$ & $\begin{array}{c}83.14 * * * \\
(13.52)\end{array}$ & $\begin{array}{c}92.08^{* * *} \\
(14.35)\end{array}$ \\
\hline CEO indicator & $\begin{array}{c}417.61^{* * * *} \\
(32.34)\end{array}$ & $\begin{array}{c}417.37 * * * \\
(32.33)\end{array}$ & $\begin{array}{c}424.73^{* * * *} \\
(30.25)\end{array}$ & $\begin{array}{c}416.29 * * * \\
(32.37)\end{array}$ & $\begin{array}{c}415.72^{* * * *} \\
(32.05)\end{array}$ & $\begin{array}{c}424.36 * * * \\
(31.95)\end{array}$ & $\begin{array}{c}422.75 * * * \\
(29.98)\end{array}$ \\
\hline Female indicator & $\begin{array}{c}-47.98 * * * \\
(-4.44)\end{array}$ & $\begin{array}{c}-49.40 * * * \\
(-4.53)\end{array}$ & $\begin{array}{c}-51.34 * * * \\
(-4.28)\end{array}$ & $\begin{array}{c}-51.93^{* * *} \\
(-4.89)\end{array}$ & $\begin{array}{c}-49.20 * * * \\
(-4.55)\end{array}$ & $\begin{array}{c}-50.58 * * * \\
(-4.54)\end{array}$ & $\begin{array}{c}-56.92 * * * \\
(-4.80)\end{array}$ \\
\hline Year dummies & Yes & Yes & Yes & Yes & Yes & Yes & Yes \\
\hline Two digit SIC dummies & Yes & Yes & Yes & Yes & Yes & Yes & Yes \\
\hline Adjusted $\mathrm{R}^{2}$ & 0.22 & 0.22 & 0.23 & 0.26 & 0.22 & 0.22 & 0.27 \\
\hline Number of observations & 119,281 & 119,281 & 102,537 & 119,079 & 118,149 & 113,496 & 100,760 \\
\hline
\end{tabular}


Table 5

\section{Effect of Profitability Uncertainty on Investment Volatility}

The table presents the OLS regression results on the effects of profitability uncertainty on investment volatility. The dependent variable is the investment volatility (invvol). All the explanatory variables are lagged by one year. The sample includes all the companies in ExecuComp and covers the period from 1992 to 2008. The detailed definitions of all the variables are in Appendix B. Heteroskedasticity robust t-statistics adjusting for clustering within companies are in parentheses. Significance at the $10 \%$, $5 \%$, and $1 \%$ levels is indicated by $*, * *$, and $* * *$.

\begin{tabular}{|c|c|c|}
\hline Dependent variable $=$ investment volatility & Expected sign & (1) \\
\hline \multicolumn{3}{|l|}{ Profitability uncertainty variables } \\
\hline Log(firm age) & - & $\begin{array}{c}-1.16 * * * \\
(-5.54)\end{array}$ \\
\hline ERC & + & $\begin{array}{l}0.001 \\
(0.08)\end{array}$ \\
\hline Market to book & + & $\begin{array}{c}0.45^{* * *} \\
(4.50)\end{array}$ \\
\hline Tangibility & - & $\begin{array}{c}-10.00 * * * \\
(-6.63)\end{array}$ \\
\hline Analyst forecast error & + & $\begin{array}{c}0.22 \\
(1.19)\end{array}$ \\
\hline \multicolumn{3}{|l|}{ Risk variable } \\
\hline Stock return volatility & & $\begin{array}{c}13.07 * * * \\
(6.97)\end{array}$ \\
\hline \multicolumn{3}{|l|}{ Control variables } \\
\hline Firm size & & $\begin{array}{c}-0.03 \\
(-0.21)\end{array}$ \\
\hline Profitability & & $\begin{array}{c}-5.02 * * * \\
(-3.18)\end{array}$ \\
\hline Capital expenditure & & $\begin{array}{c}21.59 * * * \\
(6.16)\end{array}$ \\
\hline Advertisement & & $\begin{array}{c}-0.17 \\
(-0.04)\end{array}$ \\
\hline Advertisement missing dummy & & $\begin{array}{c}-0.27 \\
(-0.80)\end{array}$ \\
\hline Leverage & & $\begin{array}{c}-0.52 \\
(-0.60)\end{array}$ \\
\hline Dividend paying indicator & & $\begin{array}{c}0.18 \\
(0.52)\end{array}$ \\
\hline CEO chair indicator & & $\begin{array}{c}0.37 \\
(1.52)\end{array}$ \\
\hline Fraction of inside directors & & $\begin{array}{c}2.52 * * * \\
(2.68)\end{array}$ \\
\hline Log(tenure) & & $\begin{array}{c}-0.42^{* * *} \\
(-2.62)\end{array}$ \\
\hline CEO indicator & & $\begin{array}{l}0.17^{* *} \\
(2.48)\end{array}$ \\
\hline Female indicator & & $\begin{array}{c}0.32 \\
(1.17)\end{array}$ \\
\hline Year dummies & & Yes \\
\hline Two digit SIC dummies & & Yes \\
\hline Adjusted $\mathrm{R}^{2}$ & & 0.19 \\
\hline Number of observations & & 95,773 \\
\hline
\end{tabular}


Table 6

\section{Robustness Analysis}

The table presents the robustness analysis results on the effects of profitability uncertainty and risk on incentives. Panel A contains OLS regressions with the volatility variable being dollar return volatility. Panel B reports OLS regressions with the dependent variable being the percentage-to-percentage measure (i.e., wealth-performance sensitivity or WPS) proposed in Edmans et al. (2009). Panel C contains median regression results. Panel D is median regressions with the volatility variable being dollar return volatility. Panel $\mathrm{E}$ is firm-manager paired fixed effect regression results, in which there is one fixed effect for each unique firm-manager combination. Unless mentioned, the return volatility is percentage return volatility. The dependent variable is the dollar-to-dollar measure (PPS1) of pay-performance sensitivity in Columns (1) and (2), and is the dollar-to-percentage measure (PPS2) in Columns (3) and (4). In Panel B, the values of WPS for each individual executive are available from Alex Edmans' website. Specifically, WPS is equal to the change in $\ln$ (executive wealth) divided by the change in $\ln ($ firm value). This measure is also equal to PPS2 divided by TDC1, where TDC1 is the total compensation of an executive. In the regressions, WPS is winsorized at $99 \%$ to deal with outliers. All the specifications include the same control variables as those in Table 3, but to save space, the coefficient estimates on these control variables are not reported. All the explanatory variables are lagged by one year. The sample includes all the companies in ExecuComp and covers the period from 1992 to 2008. The detailed definitions of all the variables are in Appendix B. For median regressions, t-statistics derived from the bootstrapped standard errors (based on 20 replications) are in parentheses. For OLS (firm-manager fixed effect) regressions, heteroskedasticity robust t-statistics adjusting for clustering within companies (firm-manager pairs) are in parentheses. Significance at the $10 \%, 5 \%$, and $1 \%$ levels is indicated by *, **, and ***.

Panel A: Dollar return volatility and OLS regressions

\begin{tabular}{|c|c|c|c|c|c|}
\hline Dependent variable = PPS1 or PPS2 & Expected sign & (1) PPS1 & (2) PPS1 & (3) PPS2 & (4) PPS2 \\
\hline \multicolumn{6}{|l|}{ Profitability uncertainty variables } \\
\hline Log(firm age) & - & -- & $\begin{array}{c}-0.29 * * * \\
(-7.24)\end{array}$ & -- & $\begin{array}{c}-42.17 * * * \\
(-5.56)\end{array}$ \\
\hline ERC & + & -- & $\begin{array}{c}0.006^{* * *} \\
(3.10)\end{array}$ & -- & $\begin{array}{c}1.21^{* * *} \\
(3.57)\end{array}$ \\
\hline Market to book & + & -- & $\begin{array}{c}0.05^{* * *} \\
(2.97)\end{array}$ & -- & $\begin{array}{c}72.75 * * * \\
(12.76)\end{array}$ \\
\hline Tangibility & - & -- & $\begin{array}{l}-0.33^{*} \\
(-1.66)\end{array}$ & -- & $\begin{array}{c}-132.09 * * * \\
(-3.68)\end{array}$ \\
\hline Analyst forecast error & + & -- & $\begin{array}{l}0.05^{* *} \\
(2.02)\end{array}$ & -- & $\begin{array}{c}4.61 \\
(1.20)\end{array}$ \\
\hline \multicolumn{6}{|l|}{ Risk variable } \\
\hline Rank of dollar return volatility & - & $\begin{array}{c}-0.006 * * * \\
(-3.70)\end{array}$ & $\begin{array}{c}-0.008 * * * \\
(-5.28)\end{array}$ & $\begin{array}{c}3.53^{* * *} \\
(10.98)\end{array}$ & $\begin{array}{l}-0.20 \\
(-0.47)\end{array}$ \\
\hline $\begin{array}{l}\text { Control variables, year dummies, and } \\
\text { two digit SIC dummies }\end{array}$ & & Yes & Yes & Yes & Yes \\
\hline Adjusted $\mathrm{R}^{2}$ & & 0.23 & 0.23 & 0.25 & 0.29 \\
\hline Number of observations & & 92,970 & 80,642 & 92,970 & 80,642 \\
\hline
\end{tabular}


Panel B: OLS regressions with the dependent variable being wealth-performance sensitivity

\begin{tabular}{|c|c|c|c|c|c|}
\hline Dependent variable = WPS & $\begin{array}{l}\text { Expected } \\
\text { sign }\end{array}$ & $\begin{array}{l}\text { (1) Risk is } \\
\text { measured by } \\
\text { percent return } \\
\text { volatility }\end{array}$ & $\begin{array}{l}\text { (2) Risk is } \\
\text { measured by } \\
\text { percent return } \\
\text { volatility }\end{array}$ & $\begin{array}{l}\text { (3) Risk is } \\
\text { measured by } \\
\text { rank of dollar } \\
\text { return } \\
\text { volatility }\end{array}$ & $\begin{array}{l}\text { (4) Risk is } \\
\text { measured by } \\
\text { rank of dollar } \\
\text { return } \\
\text { volatility }\end{array}$ \\
\hline
\end{tabular}

\section{Profitability uncertainty variables}

\begin{tabular}{|c|c|c|c|c|c|}
\hline Log(firm age) & - & -- & $\begin{array}{c}-12.88 * * * \\
(-4.28)\end{array}$ & -- & $\begin{array}{c}-11.44^{* * *} \\
(-3.71)\end{array}$ \\
\hline ERC & + & -- & $\begin{array}{c}0.35^{* *} \\
(2.35)\end{array}$ & -- & $\begin{array}{c}0.30^{* *} \\
(1.97)\end{array}$ \\
\hline Market to book & + & -- & $\begin{array}{c}12.12^{* * *} \\
(5.04)\end{array}$ & -- & $\begin{array}{c}10.23^{* * *} \\
(3.90)\end{array}$ \\
\hline Tangibility & - & -- & $\begin{array}{l}11.12 \\
(0.73)\end{array}$ & -- & $\begin{array}{l}18.38 \\
(1.07)\end{array}$ \\
\hline lalyst forecast error & + & -- & $\begin{array}{c}1.73 \\
(1.12)\end{array}$ & -- & $\begin{array}{c}1.86 \\
(1.28)\end{array}$ \\
\hline
\end{tabular}

Risk variable

Stock return volatility $\quad-\quad 13.96$

Rank of dollar return volatility

$-17.40$

-- $0.81^{* * *} \quad 0.38^{*}$

(4.74) (1.73)

Control variables, year dummies, and two digit SIC dummies

Adjusted $\mathrm{R}^{2}$

Yes

(1)

\begin{tabular}{ccccc} 
two digit SIC dummies & Yes & & & Yes \\
\hline Adjusted $\mathrm{R}^{2}$ & 0.09 & 0.12 & 0.11 & 0.12 \\
Number of observations & 117,238 & 99,730 & 92,424 & 80,425 \\
\hline
\end{tabular}

Panel C: Median regressions

\begin{tabular}{|c|c|c|c|c|c|}
\hline Dependent variable = PPS1 or PPS2 & Expected sign & (1) PPS1 & (2) PPS1 & (3) PPS2 & (4) PPS2 \\
\hline \multicolumn{6}{|l|}{ Profitability uncertainty variables } \\
\hline Log(firm age) & - & -- & $\begin{array}{c}-0.03^{* * * *} \\
(-18.64)\end{array}$ & -- & $\begin{array}{r}-5.37 * * * \\
(-21.13)\end{array}$ \\
\hline ERC & + & -- & $\begin{array}{l}0.0008^{* * *} \\
(7.68)\end{array}$ & -- & $\begin{array}{c}0.16^{* * *} \\
(7.20)\end{array}$ \\
\hline Market to book & + & -- & $\begin{array}{c}-0.0003 \\
(-0.31)\end{array}$ & -- & $\begin{array}{c}23.67 * * * \\
(61.08)\end{array}$ \\
\hline Tangibility & - & -- & $\begin{array}{c}-0.20 * * * \\
(-23.63)\end{array}$ & -- & $\begin{array}{c}-31.79 * * * \\
(-16.92)\end{array}$ \\
\hline Analyst forecast error & + & -- & $\begin{array}{c}-0.01 * * * \\
(-2.84)\end{array}$ & -- & $\begin{array}{c}0.02 \\
(0.06)\end{array}$ \\
\hline \multicolumn{6}{|l|}{ Risk variable } \\
\hline Stock return volatility & - & $\begin{array}{c}0.20 * * * \\
(16.25)\end{array}$ & $\begin{array}{c}0.16^{* * *} \\
(14.06)\end{array}$ & $\begin{array}{c}19.93 * * * \\
(13.24)\end{array}$ & $\begin{array}{c}0.40 \\
(0.28)\end{array}$ \\
\hline $\begin{array}{l}\text { Control variables, year dummies, and } \\
\text { two digit SIC dummies }\end{array}$ & & Yes & Yes & Yes & Yes \\
\hline Pseudo $\mathrm{R}^{2}$ & & 0.11 & 0.11 & 0.10 & 0.13 \\
\hline Number of observations & & 119,281 & 100,760 & 119,281 & 88,489 \\
\hline
\end{tabular}


Panel D: Dollar return volatility and median regressions

\begin{tabular}{|c|c|c|c|c|c|}
\hline Dependent variable $=$ PPS1 or PPS2 & Expected sign & (1) PPS1 & (2) PPS1 & (3) PPS2 & (4) PPS2 \\
\hline \multicolumn{6}{|l|}{ Profitability uncertainty variables } \\
\hline Log(firm age) & - & -- & $\begin{array}{l}-0.05^{* * *} \\
(-18.76)\end{array}$ & -- & $\begin{array}{c}-7.75^{* * *} \\
(-16.89)\end{array}$ \\
\hline ERC & + & -- & $\begin{array}{l}0.0007 * * * \\
(6.50)\end{array}$ & -- & $\begin{array}{c}0.19 * * * \\
(7.28)\end{array}$ \\
\hline Market to book & + & -- & $\begin{array}{c}0.009 * * * \\
(6.22)\end{array}$ & -- & $\begin{array}{c}32.14 * * * \\
(47.61)\end{array}$ \\
\hline Tangibility & - & -- & $\begin{array}{c}-0.27 * * * \\
(-15.26)\end{array}$ & -- & $\begin{array}{c}-40.89 * * * \\
(-19.44)\end{array}$ \\
\hline Analyst forecast error & + & -- & $\begin{array}{c}-0.008 * * \\
(-2.56)\end{array}$ & -- & $\begin{array}{l}0.79 * * \\
(2.01)\end{array}$ \\
\hline \multicolumn{6}{|l|}{ Risk variable } \\
\hline Rank of dollar return volatility & - & $\begin{array}{c}-0.001 * * * \\
(-10.16)\end{array}$ & $\begin{array}{c}-0.002 * * * \\
(-13.87)\end{array}$ & $\begin{array}{c}0.96 * * * \\
(45.26)\end{array}$ & $\begin{array}{c}-0.16 * * * \\
(-5.51)\end{array}$ \\
\hline $\begin{array}{l}\text { Control variables, year dummies, } \\
\text { and two digit SIC dummies }\end{array}$ & & Yes & Yes & Yes & Yes \\
\hline Pseudo $\mathrm{R}^{2}$ & & 0.12 & 0.12 & 0.11 & 0.14 \\
\hline Number of observations & & 92,970 & 80,642 & 92,970 & 80,642 \\
\hline
\end{tabular}

Panel E: Fixed effect regressions

\begin{tabular}{|c|c|c|c|c|c|}
\hline Dependent variable = PPS1 or PPS2 & Expected sign & (1) PPS1 & (2) PPS1 & (3) PPS2 & (4) PPS2 \\
\hline \multicolumn{6}{|l|}{ Profitability uncertainty variables } \\
\hline Log(firm age) & - & -- & $\begin{array}{c}-0.53 * * * \\
(-5.94)\end{array}$ & -- & $\begin{array}{c}-152.16^{* * *} \\
(-8.59)\end{array}$ \\
\hline ERC & + & -- & $\begin{array}{c}0.003 * * * \\
(3.23)\end{array}$ & -- & $\begin{array}{c}0.09 \\
(0.41)\end{array}$ \\
\hline Market to book & + & -- & $\begin{array}{l}0.001 \\
(0.09)\end{array}$ & -- & $\begin{array}{l}55.51 * * * \\
(20.94)\end{array}$ \\
\hline Tangibility & - & -- & $\begin{array}{c}-0.67 * * * \\
(-3.66)\end{array}$ & -- & $\begin{array}{l}-36.84 \\
(-1.01)\end{array}$ \\
\hline Analyst forecast error & + & -- & $\begin{array}{c}-0.01 \\
(-1.00)\end{array}$ & -- & $\begin{array}{l}-2.25 \\
(-1.19)\end{array}$ \\
\hline \multicolumn{6}{|l|}{ Risk variable } \\
\hline Stock return volatility & - & $\begin{array}{c}-0.45^{* * *} \\
(-3.08)\end{array}$ & $\begin{array}{c}-0.80 * * \\
(-5.19)\end{array}$ & $\begin{array}{l}-109.28 * * * \\
\quad(-4.17)\end{array}$ & $\begin{array}{l}-127.72^{* * *} \\
\quad(-4.00)\end{array}$ \\
\hline $\begin{array}{l}\text { Control variables, year dummies, and } \\
\text { firm-manager paired fixed effects }\end{array}$ & & Yes & Yes & Yes & Yes \\
\hline Adjusted $\mathrm{R}^{2}$ & & 0.85 & 0.87 & 0.78 & 0.80 \\
\hline Number of observations & & 119,365 & 100,835 & 119,365 & 100,835 \\
\hline
\end{tabular}

